\title{
INTEGRIN-MEDIATED INTERACTIONS WITH A LAMININ- PRESENTING SUBSTRATE MODULATE BIOSYNTHESIS AND PHENOTYPIC EXPRESSION FOR CELLS OF THE HUMAN NUCLEUS PULPOSUS
}

\author{
J. Speer ${ }^{1}$, M. Barcellona ${ }^{1}$, L. Jing ${ }^{1}$, B. Liu ${ }^{1}$, M. Lu', M. Kelly ${ }^{2}$, J. Buchowski², L. Zebala ${ }^{2}$, S. Luhmann², \\ M. Gupta ${ }^{2}$ and L. Setton ${ }^{1,2, *}$ \\ ${ }^{1}$ Department of Biomedical Engineering, Washington University in St. Louis; St. Louis, MO, USA \\ ${ }^{2}$ Department of Orthopedic Surgery, Washington University School of Medicine; St. Louis, MO, USA
}

\begin{abstract}
With aging and pathology, cells of the nucleus pulposus (NP) de-differentiate towards a fibroblast-like phenotype, a change that contributes to degeneration of the intervertebral disc (IVD). Laminin isoforms are a component of the NP extracellular matrix during development but largely disappear in the adult NP tissue. Exposing human adult NP cells to hydrogels made from PEGylated-laminin-111 (PEGLM) has been shown to regulate NP cell behaviors and promote cells to assume a biosynthetically active state with gene/protein expression and morphology consistent with those observed in juvenile NP cells. However, the mechanism regulating this effect has remained unknown. In the present study, the integrin subunits that promote adult degenerative NP cell interactions with laminin-111 are identified by performing integrin blocking studies along with assays of intracellular signaling and cell phenotype. The findings indicate that integrin $\alpha 3$ is a primary regulator of cell attachment to laminin and is associated with phosphorylation of signaling molecules downstream of integrin engagement (ERK $1 / 2$ and GSK3 $\beta$ ). Sustained effects of blocking integrin $\alpha 3$ were also demonstrated including decreased expression of phenotypic markers, reduced biosynthesis, and altered cytoskeletal organization. Furthermore, blocking both integrin $\alpha 3$ and additional integrin subunits elicited changes in cell clustering, but did not alter the phenotype of single cells. These findings reveal that integrinmediated interactions through integrin $\alpha 3$ are critical in the process by which NP cells sense and alter phenotype in response to culture upon laminin and further suggest that targeting integrin $\alpha 3$ has potential for reversing or slowing degenerative changes to the NP cell.
\end{abstract}

Keywords: Intervertebral disc, mechanobiology, biomaterials, signal transduction.

*Address for correspondence: Dr. Lori A. Setton, Department of Biomedical Engineering, Washington University in St. Louis, 1 Brookings Drive, Campus Box 1097, St. Louis, MO 63130, USA.

Telephone number: +1 3149356164 Email: setton@wustl.edu

Copyright policy: This article is distributed in accordance with Creative Commons Attribution Licence (http://creativecommons.org/licenses/by-sa/4.0/).

\begin{tabular}{|c|c|c|c|}
\hline & List of Abbreviations & FBS & fetal bovine serum \\
\hline & & FUNCAT & functional noncanonical amino acid \\
\hline ACAN & aggrecan & & tagging \\
\hline ANOVA & analysis of variance & GAPDH? & glyceraldehyde 3-phosphate \\
\hline BASP1 & brain acid soluble protein 1 & & dehydrogenase \\
\hline BSA & bovine serum albumin & GLUT1 & glucose transporter 1 \\
\hline COL2A1 & collagen type II alpha 1 chain & GSK & glycogen synthase kinase \\
\hline $\mathrm{CDH} 2$ & $\mathrm{~N}$-cadherin & HEPES & 4-(2-hydroxyethyl)-1- \\
\hline DAPI & 4'-6-diamidino-2-phenylindole & & piperazineethanesulfonic acid \\
\hline $\mathrm{DBCO}$ & dibenzylcyclooctyne & $\operatorname{IgG}$ & immunoglobulin G \\
\hline DMEM & Dulbecco's modified Eagle's medium & IVD & intervertebral disc \\
\hline DMMB & dimethylmethylene blue & LM & laminin \\
\hline ECM & extracellular matrix & MAPK & mitogen-activated protein kinase \\
\hline EDTA & ethylenediamine tetraacetic acid & MFI & mean fluorescence intensities \\
\hline ERK & extracellular-signal-regulated kinase & MR & magnetic resonance \\
\hline FA & focal adhesions & $\mathrm{NP}$ & nucleus pulposus \\
\hline
\end{tabular}




\begin{tabular}{|c|c|}
\hline PBS & phosphate-buffered saline \\
\hline PEG & (poly)ethylene glycol \\
\hline PEGLM & $\begin{array}{l}\text { laminin-111-functionalized } \\
\text { polyethylene glycol }\end{array}$ \\
\hline PFA & paraformaldehyde \\
\hline qPCR & quantitative polymerase chain reaction \\
\hline RLT buffer & $\begin{array}{l}\text { a lysis buffer for lysing cells and } \\
\text { tissues }\end{array}$ \\
\hline RT-qPCR & quantitative reverse transcription PCR \\
\hline sGAG & sulfated glycosaminoglycan \\
\hline YAP & Transcriptional coactivator YAP1 \\
\hline
\end{tabular}

\section{Introduction}

The IVD is comprised of several major structures, namely the NP, anulus fibrosus, and cartilaginous endplates (Chan et al., 2011; Urban and Roberts, 2003). Together these structures contribute flexibility and motion to the spine, and distribute mechanical forces exerted on the axial skeleton (Fearing et al., 2018; Freemont, 2008; Nachemson, 1981; NeidlingerWilke et al., 2014; Roughley, 2004; Setton and Chen, 2006). With aging and degeneration, changes to the IVD are believed to initiate in the NP region including decreased cellularity, hydration, tissue stiffening and a consequent loss of disc height - all of which are hallmarks of a degenerated IVD (Chan et al., 2011; Hoy et al., 2014; Kandel et al., 2008; Weber et al., 2015). Patients presenting with these changes upon radiographic or MR imaging may have impaired physical function, pain upon motion, and associated disability (Hoy et al., 2014; Lim et al., 2005). For these reasons, low-back pain, and degenerative conditions of the IVD represent a major medical and socioeconomic burden (Hoy et al., 2014; Katz, 2006; Ravindra et al., 2018).

The degenerative changes in the NP can be observed across several length scales. In the healthy, juvenile state, the avascular and aneural NP is comprised of notochord-derived NP cells present in a soft matrix ( 0.5-1 kPa measured in human lumbar discs) (Cloyd et al., 2007; Iatridis et al., 1996; Iatridis et al., 1997) that is highly hydrated ( $90 \%$ water by wet weight) (Bowles et al., 2014; Iatridis et al., 1996; Urban and Roberts, 1995). The ECM of the juvenile NP is comprised of collagens (predominantly Type II), proteoglycans (particularly ACAN) and LM, including LM-111, -121, -332, -511 and -521, amongst other non-collagenous proteins (Bowles et al., 2014; Chen et al., 2009; Hayes et al., 2001; Roughley, 2004; Tang et al., 2014). In contrast, the degenerative NP is significantly stiffer (10-20 kPa), less hydrated, with a higher ratio of collagen to proteoglycan, and has other alterations to ECM composition (Chen et al., 2009; Cloyd et al., 2007; Gilchrist et al., 2013; Hwang et al., 2014; Iatridis et al., 1997; Urban et al., 2000; Walter et al., 2017). The NP cells themselves are also observed to change with maturation and degeneration juvenile NP cells are rounded, vacuolated, exist in a clustered morphology, and are biosynthetically active (Bowles et al., 2014; Gilchrist et al., 2013; Risbud et al., 2015; Urban et al., 2000). With maturation and degeneration, cells transition towards a more elongated morphology and express markers of a fibroblast-like phenotype (Bowles et al., 2014; Gilchrist et al., 2013; Risbud et al., 2015; Roughley, 2004; Urban et al., 2000). Together, aging and degeneration result in an NP of lower cell density with a limited capacity for self-repair that can contribute to progressive damage to the IVD, pathology and associated pain and disability (Freemont, 2008; Iatridis et al., 1997; Pfirrmann et al., 2001; Urban et al., 2000).

Both cell-based and biomaterial strategies have been explored as options to treat the degenerated disc towards the goal of slowing or reversing degeneration. Biomaterials have been coupled to many types of ECM proteins in order to regulate phenotype for the entrapped or encapsulated cells giving rise to bioactive materials that may support regeneration for the targeted tissue (Bowles et al., 2014; Choi et al., 2019; Clouet et al., 2019). For the IVD, a large body of work has shown that NP cell phenotype can be modulated through culture on substrates that present LM proteins or LM-mimetic peptides (Barcellona et al., 2020; Bridgen et al., 2017; Francisco et al., 2013; Francisco et al., 2014; Gilchrist et al., 2011a; Humphreys et al., 2018; Hwang et al., 2015). These studies have demonstrated that NP cell behaviors (attachment, morphology, biosynthesis and phenotype) are a function of bulk substrate stiffness and ligand presentation and density (Barcellona et al., 2020; Bridgen et al., 2017; Francisco et al., 2013; Francisco et al., 2014; Gilchrist et al., 2011a; Humphreys et al., 2018; Hwang et al., 2015). The mechanisms that mediate NP cell attachment and interaction with LM are not well understood, nor are the pathways that transduce these extracellular cues from the LM-presenting biomaterial to promote gene expression of phenotypic markers consistent with healthy NP cells.

Integrins are well-demonstrated to form mechanosensitive links between proteins in the extracellular domain and the cellular cytoskeleton (Chen et al., 2016; Humphries et al., 2006; Hynes and Naba, 2012; Winograd-Katz et al., 2014). Integrins are heterodimeric proteins made of $\alpha$ and $\beta$ subunits and specific heterodimers have been shown to bind to particular ECM proteins and peptide sequences (Fig. 1) (Barczyk et al., 2010; Belkin and Stepp, 2000; Faull and Ginsberg, 1996; Humphries et al., 2006; Hwang et al., 2014; Hynes, 1992; Rasmussen and Karsdal, 2016; Takada et al., 2007). NP cells have been shown to express several laminin-binding integrin subunits (namely $\alpha 3, \alpha 6, \alpha 5$, and $\beta 1$ ) although the expression of these integrins has been shown to demonstrate variability based on species, age, and pathology (Bridgen et al., 2013; Chen et al., 2009; Gilchrist et al., 2007; Xia and Zhu, 2008). While studies have identified these differences in integrin expression, it remains unclear whether the events of disc degeneration cause altered integrin expression, or whether dysregulation of integrins contributes to 



Fig. 1. Integrin subunits facilitate cell binding to ECM proteins. Schematic of integrin subunits known to bind ECM proteins (left) and to regions along the laminin protein (right). Created using BioRender.com.

disc degeneration. Specifically, Xia and Zhu (2008) have demonstrated that integrins $\alpha 5$ and $\beta 1$ (but not integrins $\alpha 1, \alpha 2, \alpha \mathrm{v}$, and $\beta 3$ ) were differentially expressed in samples from patients with particular degenerative sub-phenotypes (protrusions and extrusions). Other studies, however, have not found differential expression of integrins $\alpha 5$ and $\beta 1$ between degenerative and nondegenerative samples (Le Maitre et al., 2009) and additional studies are required to understand the roles and dynamics of integrin expression in the degenerative and regenerative processes.

Data from NP and other cell types (including fibrosarcoma cells, epithelial cells, and keratinocytes) suggest that cells attach to and interact with sequences found within the laminin protein through integrins including $\alpha 3 \beta 1$ and $\alpha 6 \beta 1$ (Bridgen et al., 2013; Ferletta et al., 2003; Gilchrist et al., 2007; Kim et al., 2005; Mizushima et al., 1997; Nomizu et al., 1995; Nomizu et al., 1997; Nomizu et al., 2000; Velpula et al., 2012; Zhu et al., 2018). Engagement of integrins with ECM proteins triggers activation of signaling pathways including MAPK and ERK 1/2 (Aplin et al., 2001; Ferletta et al., 2003; Francisco et al., 2013; Hood and Cheresh, 2002; Lai et al., 2001; Legate et al., 2009; Saleem et al., 2009; Velpula et al., 2012) and GSK3 $\beta / \beta$-catenin (Legate et al., 2009; Ouyang et al., 2017b). These pathways contribute to the regulation of adhesion, gene expression, cell cycle, focal adhesions, and cytoskeletal remodeling, all of which ultimately control cell survival, division, differentiation, and motility (Arboleda et al., 2003; Legate et al., 2009; Ouyang et al., 2017a; Saleem et al., 2009; Winograd-Katz et al., 2014). Altered integrin-regulated mechanotransduction has been observed in degenerative disc cells (Gilbert et al., 2010; Le Maitre et al., 2009; Tsai et al., 2014). Therefore, understanding the integrin expression profiles and integrin-mediated mechanotransduction in adult human degenerative NP cells is needed in order to optimally design materials for the treatment of degenerative disc diseases.

One bioactive material that has been engineered to modulate NP cell behaviors and to support cell delivery to degenerative discs is PEGLM (Fearing et al., 2019; Francisco et al., 2013; Francisco et al., 2014). Prior work has shown that cells interacting with PEGLM exhibit higher biosynthesis of sulfated glycosaminoglycans and markers of the juvenile NP phenotype, suggesting that it is the laminin ligand presentation that is responsible for the effect (Fearing et al., 2019; Francisco et al., 2013; Francisco et al., 2014); however, the mechanism by which NP cells interact with laminin in this biomaterial and the regulatory effects upon phenotype and synthesis remain unknown. The present study aimed to test the hypothesis that NP cells interact with the laminins in PEGLM through integrin engagement and subsequent signal transduction through the ERK and GSK3 $\beta$ pathways. Furthermore, the specific integrin subunits critical for driving the transcription of genes and translation of proteins in degenerative human NP cells that support cell morphology, biosynthesis, and markers of the juvenile NP cell phenotype when interacting with this biomaterial were identified.

\section{Materials and Methods}

\section{Primary human NP cell culture}

NP tissue was obtained from to-be-discarded surgical waste tissues (exempt from IRB review, Washington University Institutional Review Board) of patients (ages 16-75, male and female) receiving surgical treatment for degenerative conditions of the IVD; only demographic information was collected 
on each patient (age, race, and sex). NP cells were enzymatically isolated from tissues, as previously described (Bridgen et al., 2017; Fearing et al., 2019). In brief, the NP tissue was digested for $2-4 \mathrm{~h}$ at $37^{\circ} \mathrm{C}$ [0.4\% collagenase type II (Worthington Biochemical; Lakewood, NJ, USA), 0.2 \% pronase (Roche; Basel, Switzerland), and $5 \%$ FBS; $23 \mathrm{~mL} / \mathrm{g}$ tissue]. Isolated NP cells were passed through a $70 \mu \mathrm{m}$ filter and then expanded in monolayer culture using Ham's F12 media (Life Technologies; Carlsbad, CA, USA) supplemented with $1 \%$ penicillin/streptomycin and $10 \%$ FBS under $5 \% \mathrm{CO}_{2}$ and atmospheric $\mathrm{O}_{2}$ at $37^{\circ} \mathrm{C}$. Cells were not used for experimentation past passage 4 , and all experiments were conducted using at least 3 human subjects (biological replicates); assay-specific samples sizes are detailed below.

\section{PEGLM synthesis and coating of tissue culture surfaces}

PEGLM was prepared as previously described (Fearing et al., 2019; Francisco et al., 2013). Laminin-111 (LM-111, Trevigen; Gaithersburg, MD, USA) was reacted with acrylate-PEG-hydroxysuccinimide (AcPEG-NHS, 10 kDa, Creative PEGWorks; WinstonSalem, NC, USA) in order to form PEGLM. This solution was then dialyzed against PBS in order to remove unreacted Ac-PEG-NHS groups and PEGLM concentration was determined at $280 \mathrm{~nm}$ absorbance. Stiff (>1 GPa) tissue culture surfaces (i.e., polystyrene well plates or glass chamber slides; Nunc Lab-Tek Chamber Slide Systems, Thermo Fisher Scientific; Waltham, MA, USA) were coated with the PEGLM solution (diluted with sterile PBS to a working concentration of $22.5 \mu \mathrm{g} / \mathrm{mL}$ ). The PEGLM was allowed to adsorb to the culture surface overnight at $4{ }^{\circ} \mathrm{C}$. The following day, the solutions were removed, and surfaces were rinsed with sterile PBS prior to inception of the experiment.

\section{Functional inhibition of integrin subunits}

Single integrin blocking

Following detachment from culture plastic, NP cells were treated with blocking antibodies in order to reduce integrin functionality. For antibody-based inhibition, NP cells were incubated with azide-free antibodies $(20 \mu \mathrm{g} / \mathrm{mL})$ targeting integrin $\alpha 3, \alpha 4, \alpha 5$, $\alpha v, \alpha 6$, or $\beta 1$ subunits or the respective IgG control antibody for $30 \mathrm{~min}$ on a rocker at $37^{\circ} \mathrm{C}$ (Table 1) in a manner consistent with previously published integrin-blocking studies in NP and other cell types (Bridgen et al., 2013; Ferletta et al., 2003; Gilchrist et al., 2007). Following this incubation period, the cell solutions containing the antibody were then seeded directly onto the culture substrates.

\section{Double integrin blocking}

In order to determine if compensatory cell interactions with LM could occur through competing integrin subunits, double integrin-blocking experiments were performed. Single integrin blocking was conducted as before by incubating the assay-appropriate number of cells with $20 \mu \mathrm{g} / \mathrm{mL}$ of the respective antibody for 30 min before seeding the cells (in the antibodycontaining media) on PEGLM-coated substrates. After $24 \mathrm{~h}$ of culture, additional antibody $(20 \mathrm{\mu g} /$ $\mathrm{mL}, \alpha 3$ or additional integrin subunits $\alpha 5$ or $\alpha 6$ ) was added into the well without removing the prior antibody or media. $24 \mathrm{~h}$ after adding the second antibody, cells were fixed in $4 \%$ PFA and prepared for subsequent analysis.

\section{Cell attachment}

As described previously, wells of a 96-well 1/2-area plate were coated with PEGLM overnight. Serumstarved NP cells were detached from culture plastic using trypsin that was then neutralized with trypsin soybean inhibitor. The cells were then resuspended in

Table 1. Antibodies used for integrin blocking experiments and corresponding isotype control. MilliporeSigma and Sigma-Aldrich, St. Louis, MO, USA; Thermo Fisher Scientific and Fisher Scientific, Waltham, MA, USA; Invitrogen, Carlsbad, CA, USA; BioLegend; San Diego, CA, USA; SouthernBiotech; Birmingham, AL, USA.

\begin{tabular}{|c|c|c|}
\hline $\begin{array}{l}\text { Integrin } \\
\text { subunit }\end{array}$ & Anti-integrin antibody $(20 \mu \mathrm{g} / \mathrm{mL})$ & Control IgG antibody $(20 \mu \mathrm{g} / \mathrm{mL})$ \\
\hline$\alpha 3$ & $\begin{array}{c}\text { Clone P1B5, azide free } \\
\text { product: MAB1952Z (MilliporeSigma) }\end{array}$ & $\begin{array}{c}\text { Mouse IgG1, azide free } \\
\text { product: MA110407 (Thermo Fisher Scientific) }\end{array}$ \\
\hline$\alpha 4$ & $\begin{array}{l}\text { Clone 9F10, azide free } \\
\text { product: } 50-143-40 \text { (Fisher Scientific) }\end{array}$ & $\begin{array}{c}\text { Mouse IgG1, azide free } \\
\text { product: MA110407 (Thermo Fisher Scientific) }\end{array}$ \\
\hline$\alpha 5$ & $\begin{array}{c}\text { Clone P1D6, azide free } \\
\text { product: MAB1956Z (Sigma-Aldrich) }\end{array}$ & $\begin{array}{c}\text { Mouse IgG3, azide free } \\
\text { product: 0105-01 (SouthernBiotech) }\end{array}$ \\
\hline$\alpha \mathrm{v}$ & $\begin{array}{c}\text { Clone 272-17E6, azide free } \\
\text { product: MABT207 (Sigma-Aldrich) }\end{array}$ & $\begin{array}{c}\text { Mouse IgG1, azide free } \\
\text { product: MA110407 (Thermo Fisher Scientific) }\end{array}$ \\
\hline$\alpha 6$ & $\begin{array}{c}\text { Clone GoH3, azide free } \\
\text { product: MAB16884, (Thermo Fisher Scientific), } \\
313637 \text { (BioLegend) }\end{array}$ & $\begin{array}{c}\text { Rat IgG2a, azide free } \\
\text { product: } 400516 \text { (BioLegend), } \\
\text { PIPA533214 (Fisher Scientific) }\end{array}$ \\
\hline$\beta 1$ & $\begin{array}{c}\text { Clone AIIB2, azide free } \\
\text { product: MABT409 (MilliporeSigma) }\end{array}$ & $\begin{array}{c}\text { Rat IgG1, azide free } \\
\text { product: } 400414 \text { (BioLegend) }\end{array}$ \\
\hline
\end{tabular}




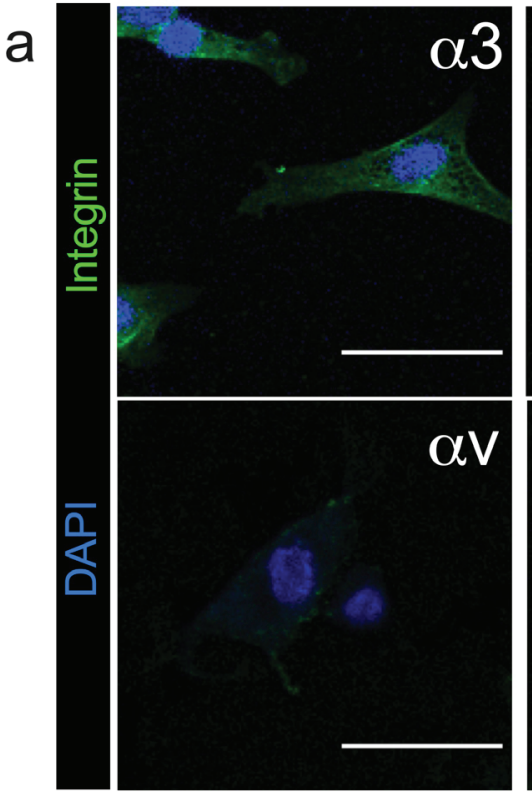

b

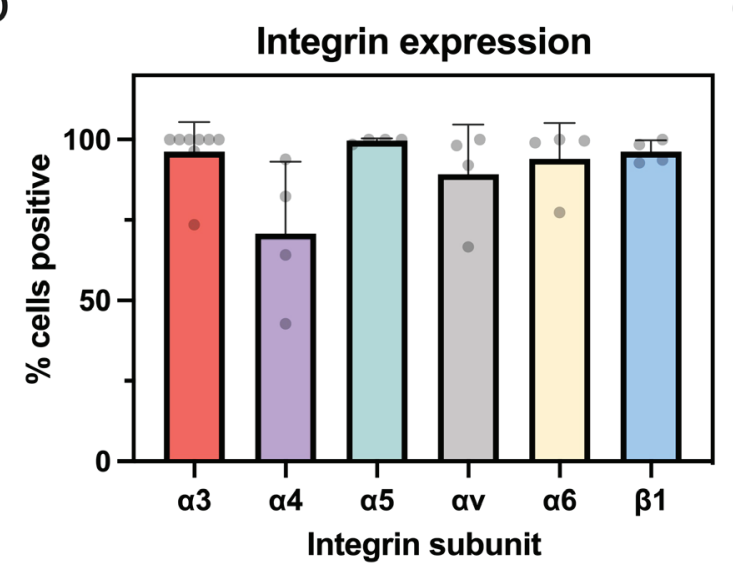

d

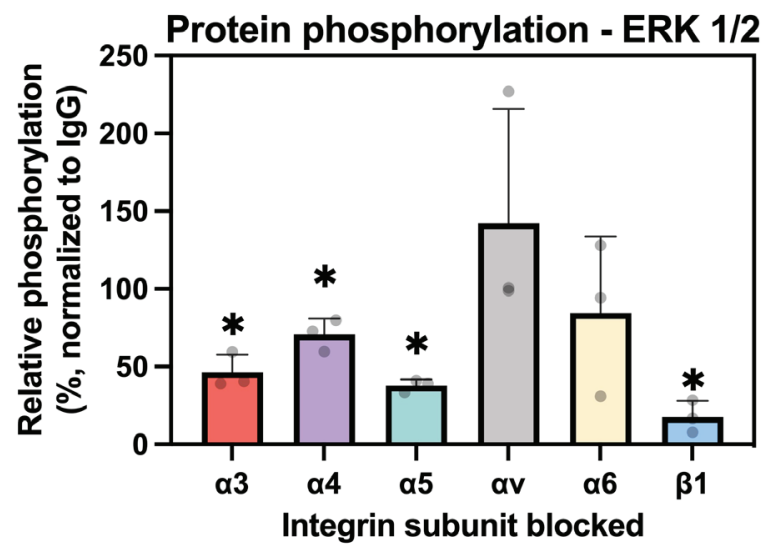

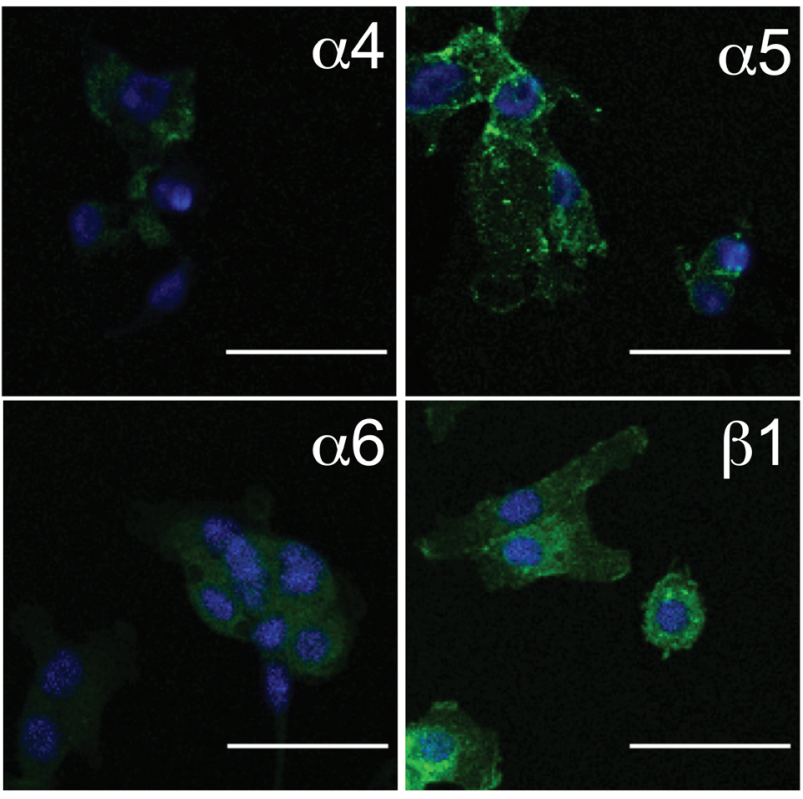

C

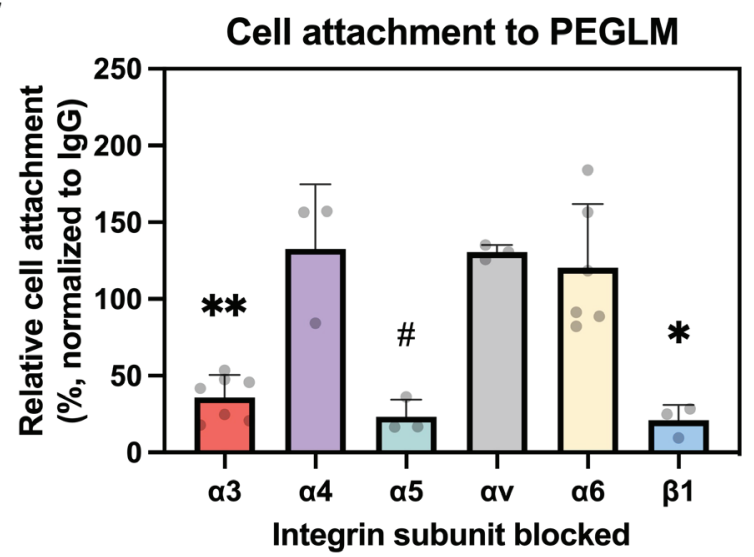

e

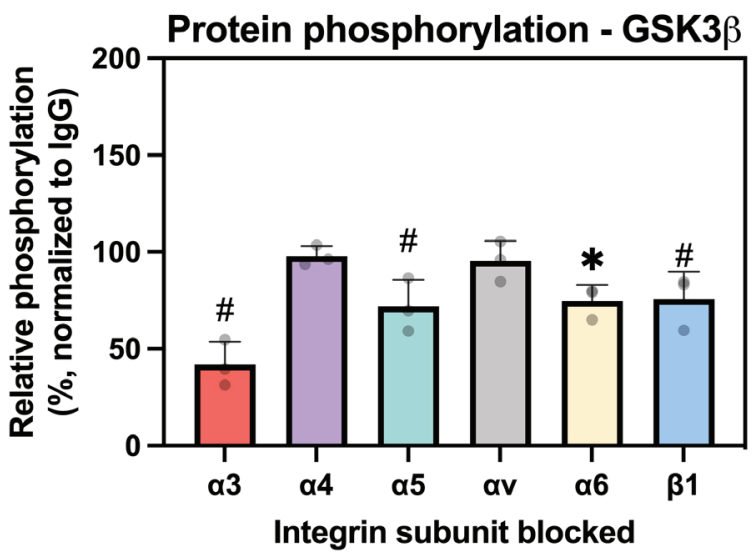

Fig. 2. Adult degenerative NP cells express integrin subunits that facilitate interactions with PEGLM. (a) Expression of integrin subunits as shown in representative images (scale bar $=50 \mu \mathrm{m}$ ) and (b) quantification of the percentage of cells positive for given integrin subunits in NP cells cultured on untreated polystyrene. (c) Relative NP cell attachment to PEGLM-coated polystyrene following integrin-blocking compared to IgG controls, relative attachment $=100 \times$ (integrin-blocked/IgG-treated). Relative protein phosphorylation of (d) ERK $1 / 2$ and (e) GSK3 $\beta$ in cells treated with function-blocking antibodies compared to cells treated with IgG control when seeded on PEGLM-coated polystyrene, relative phosphorylation $=100 \times$ (integrin-blocked/IgGtreated). For all data presented: error bars $=$ standard deviation; each dot $=$ data from 1 biological replicate; ${ }^{* *} p<0.01,{ }^{*} p<0.05, \# p<0.09$ based on results of paired one-tailed $t$-tests (integrin-blocked compared to IgG-treated). 
serum-free F-12 medium and incubated with integrinblocking or isotype-matched control antibodies $(20 \mu \mathrm{g} / \mathrm{mL})$ for $30 \mathrm{~min}$ before being seeded into wells of the 96 -well $1 / 2$-area plate, at a density of 8,000 cells per well, in a manner consistent with previous studies (Barcellona et al., 2020; Bridgen et al., 2013; Ding et al., 2014; Hiyama et al., 2010). After 2 h, cell attachment was quantified through the use of the CellTiter-Glo (Promega; Madison, WI, USA) plate-reader assay (EnSpire Multimode plate reader, PerkinElmer; Waltham, MA, USA) following manufacturers' and previously established protocols (Barcellona et al., 2020; Bridgen et al., 2013; Ding et al., 2014). Relative cell attachment was defined as $100 \times$ (integrinblocked sample/IgG-treated sample). Paired onetailed $t$-tests were used to test the hypothesis that integrin-blocked samples would exhibit reduced cell attachment compared to cells treated with the isotype control. Relative cell attachment values below $50 \%$ of the IgG were considered to be meaningfully reduced based on prior findings (Ferletta et al., 2003; Gilchrist et al., 2007).

\section{Protein phosphorylation}

Phosphorylation of the proteins ERK 1/2 (Thr202/ Tyr204), and GSK3 $\beta$ (Ser9) were quantified using AlphaLISA SureFire Ultra Assay Kits (high volume, PerkinElmer). During protocol development, the optimal time to observe maximal protein phosphorylation was determined by first comparing phosphorylation of proteins in primary NP cells cultured on PEGLM to those on BSA-coated controls or in suspension. Maximal protein phosphorylation in degenerative adult NP cells was found to occur at $15 \mathrm{~min}$ for ERK $1 / 2$ and $120 \mathrm{~min}$ for GSK3 $\beta$, time points that corroborate prior findings in the literature (Aplin et al., 2001; Blaustein et al., 2013; Ferletta et al., 2003; Francisco et al., 2013; Grzesiak et al., 2005; Tsai et al., 2007); thus, these respective times were incorporated into the protocols for all future experiments.

NP cells were detached from culture plastic using trypsin that was neutralized with trypsinsoybean inhibitor and resuspended in serum-free F-12 medium. Following incubation with integrinblocking antibodies, 10,000 NP cells were seeded into wells of a 96-well $1 / 2$-area plate (coated with PEGLM) and allowed to incubate for 15 or $120 \mathrm{~min}$, as appropriate. After the incubation period the AlphaLISA assay was performed per manufacturer's protocol. Briefly, medium was removed, and lysis buffer was added to each well. The AlphaLISA reaction buffers (donor and acceptor mixes) were then added to the lysate before wells were read using the plate reader (EnSpire Multimode) using the AlphaScreen protocol (excitation at $680 \mathrm{~nm}$, emission at $615 \mathrm{~nm}$ ). Relative phosphorylation was defined as $100 \times$ (integrin-blocked sample/IgG-treated sample). Paired one-tailed $t$-tests were used to test the hypothesis that integrin-blocked samples would exhibit reduced protein phosphorylation compared to cells treated with the isotype control. Additionally, phosphorylation below a value equivalent to $50 \%$ of the IgG was considered to be meaningfully reduced, based on prior findings (Ferletta et al., 2003; Saleem et al., 2009).

\section{Immunocytochemistry and image analysis}

NP cells were seeded at a density of 8,000-10,000 cells per chamber well and cultured for 24 h- 4 d; immunolabeling for baseline integrin expression (no integrin blocking) was performed after $24 \mathrm{~h}$ of culture on untreated polystyrene (i.e., prior to exposure to PEGLM); additional immunolabeling following integrin-blocking and culture on PEGLM was performed at $4 \mathrm{~d}$ of culture. After duration of culture, samples were fixed in $4 \%$ PFA for $10 \mathrm{~min}$, permeabilized using $0.2 \%$ Triton $\mathrm{X}-100$ in $\mathrm{PBS}^{+/+}$for $10 \mathrm{~min}$ and incubated for $30 \mathrm{~min}$ in blocking buffer (3.75\% BSA and $5 \%$ goat serum, Thermo Fisher Scientific), all at room temperature. Samples were then immunolabeled with antibodies to detect protein expression for markers of the NP cell phenotype (Risbud et al., 2015) and integrin subunits (Table 1 and Table 2) or the respective isotype-matched controls (IgG), overnight at $4{ }^{\circ} \mathrm{C}$. Additional samples were stained with rabbit-anti-Paxillin (1:100, Abcam) to quantify focal adhesion formation and/or Alexaconjugated phalloidin $(1: 200)$ to stain F-actin in the cell's cytoskeleton. AlexaFluor (Invitrogen; Carlsbad, CA, USA) secondary antibodies were applied at a dilution of $1: 200$ and nuclei were counterstained with DAPI (2 $\mu \mathrm{g} / \mathrm{mL}$, Sigma-Aldrich).

Samples were imaged using confocal microscopy (TCS- SPE with DM6 RGBV confocal microscope; Leica DFC7000 T camera; using Leica LAS X core software; Leica Microsystems) and a $20 \times$ objective. Images were analyzed using Fiji software (Schindelin et al., 2012) to quantify morphology metrics (e.g., circularity, spread area), mean fluorescence intensity of cells or cell clusters, analysis of actin fibers, and characterization of paxillin-rich focal adhesions according to established protocols (Fearing et al., 2019; Horzum et al., 2014; Püspöki et al., 2016; Sage et al., 2005; Schindelin et al., 2012). Percent of positive cells were defined as cells with MFI greater than that of the control (IgG) antibody used for immunostaining. Relative protein expression was calculated as $100 \times$ (integrin-blocked/average value of the respective control). Upregulated and downregulated protein expression following integrin blocking was defined as cells/cell clusters with MFIs showing a $50 \%$ increase or decrease in expression

Table 2. Antibodies used to detect markers of NP cell phenotype.

\begin{tabular}{|c|c|c|}
\hline Target & Species; dilution & Manufacturer \\
\hline N-cadherin & Mouse; $1: 100$ & Sigma-Aldrich \\
\hline BASP1 & Rabbit; $1: 100$ & Abcam \\
\hline Pan Cytokeratin & Mouse; $1: 100$ & Sigma-Aldrich \\
\hline Integrin $\alpha 3$ & Rabbit; $1: 100$ & Sigma-Aldrich \\
\hline
\end{tabular}


compared to the average value for cells in the control group, respectively. For quantification of integrin expression, a minimum of 180 cells were evaluated as obtained from 4-8 biological replicates per integrin subunit. Morphology (\% clustered, cell spread area, and circularity), cytoskeletal organization, and phenotypic protein expression was characterized by assessing a minimum of 25 cells per treatment group (IgG-treated or integrin-blocked) from 3 biological replicates. Lastly, focal adhesion formation was analyzed in at least 30 cells per treatment group as obtained from 3 biological replicates. For single integrin blocking studies, one-tailed unpaired $t$-tests were used to test for differences in cell spread area, circularity, protein expression, actin alignment, or focal adhesion parameters between integrin-blocked samples and the isotype control. Specifically, it was hypothesized that integrin blocking would promote a shift away from the healthy NP cell phenotype previously observed in culture on laminin-substrates (Barcellona et al., 2020; Francisco et al., 2014; Gilchrist et al., 2011a) as seen by increased cell spread area, decreased circularity, and decreased protein expression of phenotypic markers. Furthermore, as integrin blocking alters interactions with the ECM, it was hypothesized that compared to IgG-treated cells, cells subjected to integrin blocking would demonstrate reduced actin alignment and fewer elongated focal adhesions (Besser and Safran, 2006; Kim and Wirtz, 2013). Two-tailed $t$-tests were used to test for differences in integrin expression following integrin $\alpha 3$ blocking and a one-way ANOVA with Dunnett's post-hoc test was performed to test for differences between double integrin-blocked samples compared to samples blocked with integrin $\alpha 3$ alone. Additionally, Fisher Exact Tests with a FreemanHalton extension were used to test for differences in the distribution of cell morphologies between the treated and control groups. This statistical test was run on a $2 \times 3$ contingency table based on the number of cells adherent as single cells, small clusters, or large clusters in experimental groups (i.e., IgG-treated compared to integrin $\alpha 3$ or integrin $\alpha 3$ compared to integrin $\alpha 3+\alpha 5$ or integrin $\alpha 3+\alpha 6$ ).

Quantification of gene expression using RT-qPCR NP cells were detached from culture plastic using trypsin, neutralized with F-12 media, subjected to integrin blocking, and seeded into PEGLM-coated chamber slide wells at a density of 300,000 cells per well. Following $4 \mathrm{~d}$ of culture on PEGLM, NP cells were lysed using RLT buffer (Qiagen; Hilden, Germany) with $1 \% \beta$-mercaptoethanol. RNA extraction was conducted using an RNeasy mini kit with DNase I digestion (Qiagen; Hilden, Germany) according to the manufacturer's protocol. The RNA was read for concentration and quality $(260 \mathrm{~nm} / 280 \mathrm{~nm}$, NanoDrop One Spectrophotometer, Thermo Scientific; Waltham, MA, USA) and then reverse transcribed into cDNA (iScript cDNA synthesis kit, Biorad; Hercules, CA, USA); qPCR was used to determine expression levels for $A C A N, C O L 2 A 1, C D H 2, G L U T 1$, and integrin subunits (ITGB1, ITGB4, ITGA6, ITGA10, and ITGA11) compared to housekeeping genes (GAPDH and 18S); a reference sample (cells treated with the isotype control antibody) was included with each RT-qPCR reaction. mRNA was isolated from cells of 6-8 biological replicates per target. Values for fold-difference between each sample and reference sample were calculated as $2^{-\Delta \Delta \mathrm{Ct}}$. Paired one-tailed $t$-tests (of $\Delta \mathrm{Ct}$ values) were used to test the hypothesis that integrin blocking would reduce expression of phenotypic markers of NP cells ( $A C A N$, COL2A1, CDH2, and GLUT1) compared to the IgG control group. The impact of integrin blocking on the expression of integrin subunits was also evaluated using a two-tailed paired $t$-test comparing integrinblocked samples to the control group.

\section{Analysis of biosynthesis and visualization of nascent proteins}

The production of sGAG was quantified for NP cells cultured on PEGLM that had been subjected to integrin blocking or incubation with isotype control antibodies using the DMMB spectrophotometric assay (Farndale et al., 1982; Gilchrist et al., 2011a). The media were collected from wells of NP cells $(30,000$ cells per well) that had been in culture for $4 \mathrm{~d}$ before adding papain solution $(125 \mu \mathrm{g} / \mathrm{mL}$ in PBS with $5 \mathrm{mmol} / \mathrm{L}$ EDTA and $5 \mathrm{mmol} / \mathrm{L} \mathrm{L}$-cysteine) for $2 \mathrm{~h}$ at $50{ }^{\circ} \mathrm{C}$ to digest the sample. The amount of sGAG in the medium overlay and the papain-digested samples was quantified by comparing absorbance readings (525 nm) against a chondroitin sulfate standard (Sigma-Aldrich) and a medium-only control for correction against colorimetric interference. Total sGAG was determined by adding the results of the medium overlay and the digested cell sample, and then normalized to DNA content as quantified by the Quant-iT PicoGreen dsDNA kit (Invitrogen), following manufacturer's protocol. A total of 6 samples were evaluated, as obtained from 3 biological replicates. Relative biosynthesis or DNA content was calculated as $100 \times$ (integrin $\alpha 3$ blocked/IgGtreated). Paired one-tailed $t$-tests were used to test the hypothesis that integrin blocking would reduce sGAG production, but not DNA content, compared the respective control.

Production of newly synthesized proteins was further assessed through use of a FUNCAT approach (Dunham et al., 2020; McLeod and Mauck, 2016; tom Dieck et al., 2015), based on measuring an amino acid analog capable of being incorporated into newly synthesized proteins. A fluorescently tagged molecule (Dibenzocyclooctyne, DBCO; Click Chemistry Tools; Scottsdale, AZ, USA) was used to tag the amino acid analog of methionine, allowing for the visualization of proteins synthesized since the analog was present in the medium. Briefly, 2 medium solutions were prepared for use in cell culture DMEM (without L-glutamine, sodium pyruvate, HEPES, L-methionine, L-cysteine) was supplemented 
with $10 \%$ FBS, sodium pyruvate (Thermo Fisher Scientific), ascorbic acid (Sigma-Aldrich), glutamax (1: 100, Thermo Fisher Scientific), $1 \%$ penicillin/ streptomycin, L-cysteine (Sigma-Aldrich), and either L-methionine (control media, Sigma-Aldrich) or AHA (L-azidohomoalanine, an analog for L-methionine used for the labeling media, Click Chemistry Tools). Cells were removed from tissue culture flasks and resuspended in either of these two media, subjected to integrin blocking, and seeded into PEGLM coated wells as before (30,000 cells per well). After $4 \mathrm{~d}$ of culture on PEGLM, the culture medium was removed and all samples were incubated with DBCO-488 (5 mmol/L DBCO-488 diluted 1 : 165 in PBS with $1 \%$ BSA) for 40 min under cell culture conditions $\left(37{ }^{\circ} \mathrm{C}, 5 \% \mathrm{CO}_{2}\right.$, atmospheric $\left.\mathrm{O}_{2}\right)$. Afterwards, the samples were washed, fixed with $4 \%$ PFA (10 min, room temperature), and stained with AlexaFluor phalloidin-633 and DAPI ( $2 \mu \mathrm{g} / \mathrm{mL})$ to visualize cytoskeleton and nuclei. The samples were imaged, as previously described, for immunostaining (SPE DM6 Leica confocal microscope). The production of new intracellular proteins was assessed by measuring the mean fluorescence intensity for the region within the cell body (as determined by the localization of phalloidin stain) while extracellular protein synthesis was quantified by examining the fluorescence located outside of the cell body. A minimum of 18 cells per treatment group were evaluated as obtained from 3 biological replicates. Unpaired one-tailed $t$-tests were used to test for reduced nascent protein production (using MFI) both within and outside the cell in the integrin-blocked samples compared to the IgG control.

\section{Results}

Degenerative human NP cells express integrin $\alpha 3$, $\alpha 4, \alpha 5, \alpha v, \alpha 6$, and $\beta 1$ subunits

NP cells isolated from degenerative human IVD tissues were observed to express integrin $\alpha 3, \alpha 4, \alpha 5$, $\alpha \mathrm{v}, \alpha 6$, and $\beta 1$ subunits with greater than $70 \%$ of cells expressing each protein respectively following culture for $24 \mathrm{~h}$ on untreated polystyrene (Fig. $2 \mathbf{a}, \mathbf{b})$. These findings corroborate results from prior studies which have quantified protein expression of integrin subunits in human NP cells using antibodybased staining and/or flow cytometry (Bridgen et al., 2013; Chen et al., 2009; Le Maitre et al., 2009). While inter-patient variability was observed in integrin expression, the data did not demonstrate an association with patient age, nor were differences observed as a function of the patient's sex (data not shown).

Integrin $\alpha 3 \beta 1$ plays a consistent role in regulating NP cell interactions with LM substrates at early time points

NP cell attachment to PEGLM was reduced to less than $50 \%$ of the attachment observed in the IgG- treated group when integrins $\alpha 3$ or $\beta 1$ were blocked using targeted antibodies $(p=0.015$ and $p=0.045$, respectively, Fig. 2c). Blocking integrin $\alpha 5$ reduced cell attachment to levels below $50 \%$ of that seen in the IgG group, though the comparison to this control trended towards significance ( $p=0.059$, Fig. $2 c)$. In contrast, cell attachment was not reduced when integrins $\alpha 4, \alpha \mathrm{v}$, or $\alpha 6$ were blocked (Fig. 2c; $p=0.19$, $p=0.12$ and $p=0.22$, respectively).

The binding of integrins to ECM proteins is known to initiate intracellular signaling cascades including the phosphorylation of ERK $1 / 2$ and GSK3 $\beta$ that drive cell survival, proliferation, gene expression, motility, and other cellular functions. For cells seeded onto PEGLM, inhibiting integrins $\alpha 3, \alpha 4, \alpha 5$, or $\beta 1$ with function blocking antibodies significantly reduced ERK $1 / 2$ protein phosphorylation (Fig. $2 \mathrm{~d}, p=0.028, p=0.025, p=0.033$, and $p=0.016$, respectively); however, only blocking integrins $\alpha 3$, $\alpha 5$, or $\beta 1$ reduced phosphorylation below the $50 \%$ threshold. In contrast, blocking integrins $\alpha \mathrm{v}$ and $\alpha 6$ did not significantly reduce ERK $1 / 2$ phosphorylation $(p=0.20$ and $p=0.22$, respectively, Fig. 2 d). GSK3 $\beta$ phosphorylation was reduced (significantly or at levels that trended to significance) in cells where integrins $\alpha 3, \alpha 5, \alpha 6$, and $\beta 1$ were inhibited ( $p=0.051$, $p=0.0651, p=0.041$, and $p=0.086$, Fig. $2 \mathbf{e}$ ) but was not reduced by blocking $\alpha 4$ or $\alpha v(p=0.31$ and $p=0.29$, Fig. 2e). Only inhibiting integrin $\alpha 3$ reduced GSK3 $\beta$ to levels below the $50 \%$ threshold. Taking the results of cell attachment and protein phosphorylation together, it can be seen that multiple integrin subunits can contribute to early NP cell interactions with PEGLM. However, only blocking integrin $\alpha 3$ resulted in reductions below the $50 \%$ threshold for cell attachment and phosphorylation of both proteins and thus the role of this integrin was further explored in subsequent experimentation.

\section{Treatment of NP cells with antibodies to block integrin $\alpha 3$ alters cell morphology, cytoskeletal organization, and focal adhesions}

Adult degenerative NP cells treated with a function blocking antibody targeting integrin $\alpha 3$, demonstrated differences in distributions of cellular morphology compared to those treated with an isotype-control antibody ( $p=0.023$, Fig. 3a,d). In comparison to the control group, cells treated with the $\alpha 3$ antibody were observed to form fewer small clusters (2-3 cells) but attached to PEGLM more frequently as either single cells or large clusters (4+ cells). For cells that attached to the PEGLM as single cells, inhibition of integrin $\alpha 3$ resulted in increased cell spread areas and decreased circularity ( $p=0.0024$, Fig. 3b; $p=0.0003$, Fig. 3c).

In addition to changes in shape, actin fiber alignment (coherency) was reduced in single cells subsequent to the impairment of integrin $\alpha 3$ $(p=0.047$, Fig. 4a,b). Paxillin-positive FA were seen in both the integrin inhibited and control cells (Fig. 4c). Although an increase in FA circularity was observed in the integrin-blocked group ( $p=0.033$, Fig. 4 d). 

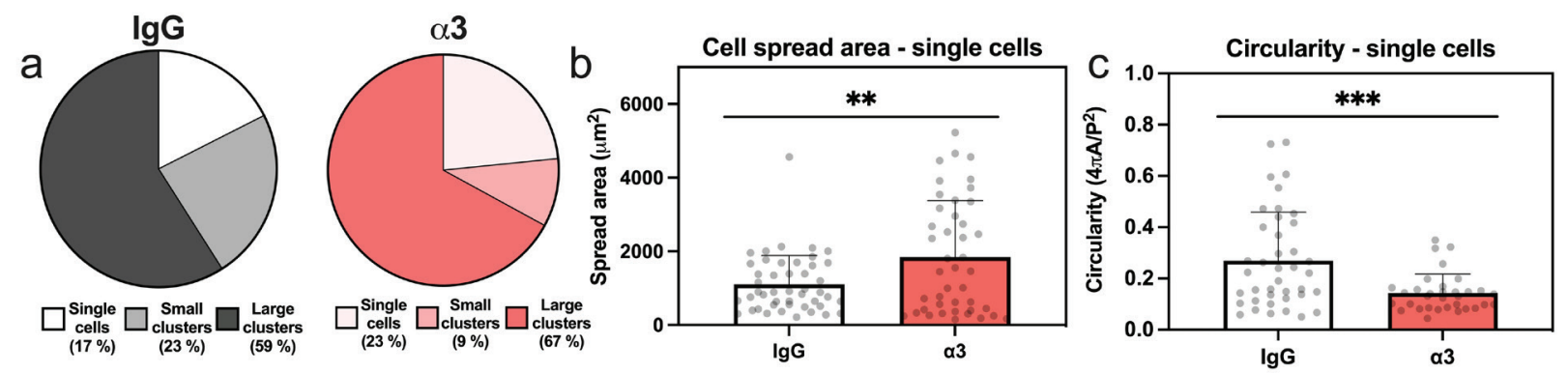

d
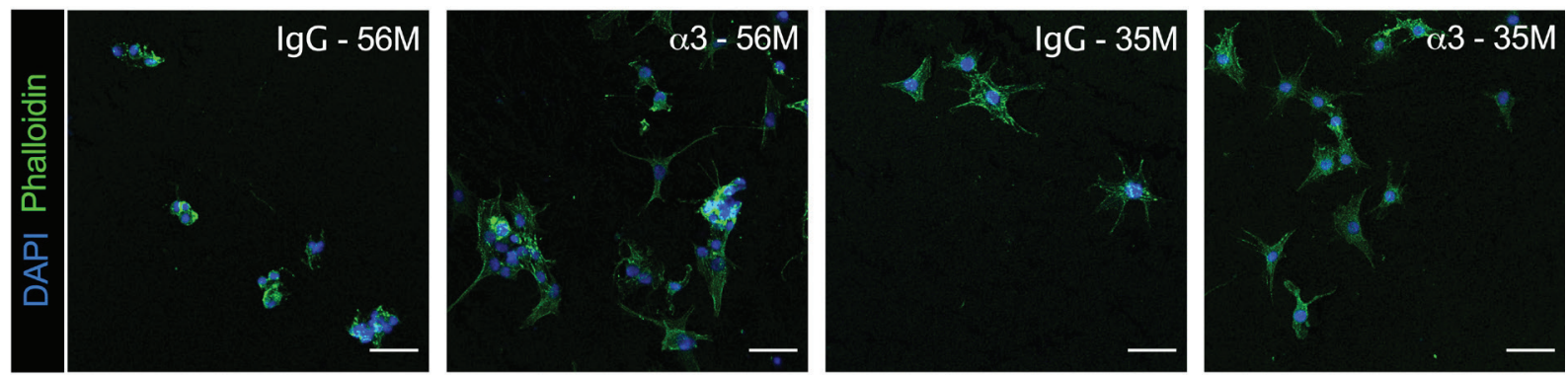

Fig. 3. Antibody blocking of integrin $\alpha 3$ alters cell morphology and shape. Characterization of cells treated with an $\alpha 3$-inhibiting or IgG control antibody: (a) \% of cells attaching to PEGLM as single cells, small clusters (2-3 cells), or large clusters (4+ cells) (b) cell spread area $\left(\mu \mathrm{m}^{2}\right)$ of single cells and (c) circularity of single cells. (d) Representative images of cell morphology in the IgG or integrin-blocked groups for cells from 2 biological replicates $(56 \mathrm{M}$ and $35 \mathrm{M})$. For all data presented: error bars $=$ standard deviation; each dot $=1$ cell as obtained from $n=3$ biological replicates; ${ }^{* * *} p<0.001,{ }^{* *} p<0.01$, based on results of unpaired one-tailed $t$-tests comparing integrin $\alpha 3$-blocked to IgG control.

a

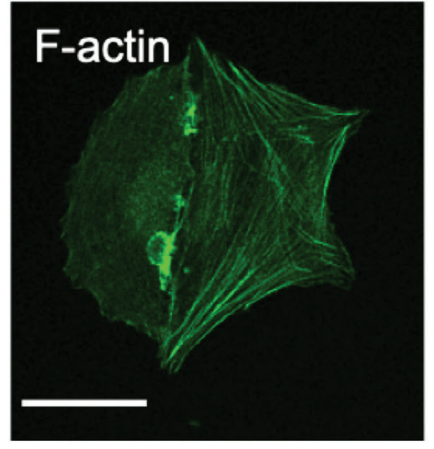

C

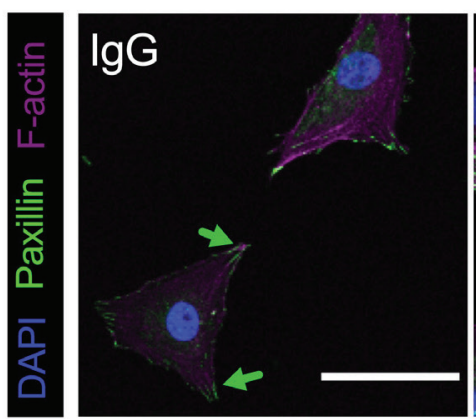

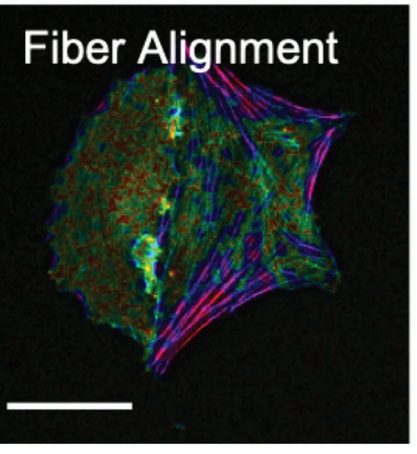

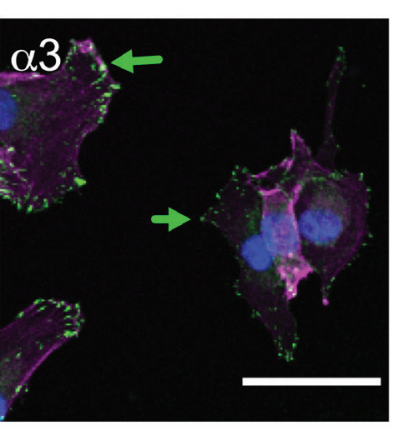

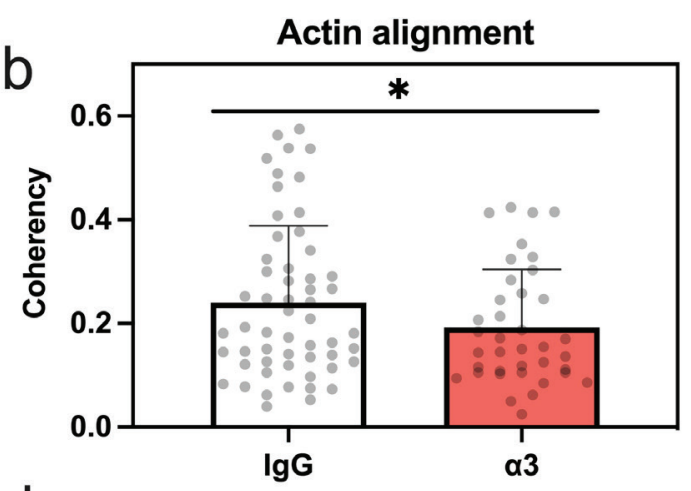

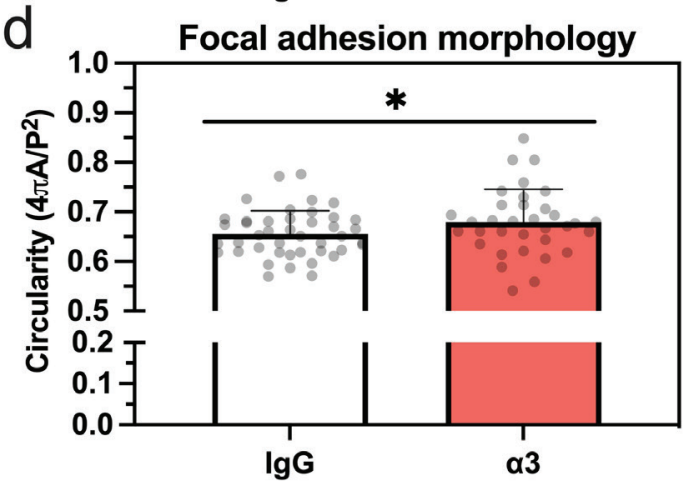

Fig. 4. Inhibition of integrin $\alpha 3$ alters actin alignment and focal adhesion morphology. (a) Representative images of phalloidin-stained F-actin (green) and processing using OrientationJ to calculate fiber alignment (color coding shows heat map of actin alignment; scale bar $=50 \mu \mathrm{m}$ ). (b) Analysis of extent of fiber alignment (coherency) for single cells in the IgG-treated or $\alpha 3$-blocked conditions where a value of 0 corresponds to unaligned fibers and a value of 1 represents perfectly aligned fibers. (c) Representative images of paxillin staining with nuclei and F-actin counterstained; scale bar $=50 \mu \mathrm{m}$, arrows indicate elongated FA formation in the IgG condition and round FA in the $\alpha 3$-blocked cells. (d) Circularity of focal adhesions in cells treated with IgG or $\alpha 3$-targeting antibodies. For all data presented: error bars $=$ standard deviation; each dot $=1$ cell as obtained from $n=3$ biological replicates; ${ }^{*} p<0.05$ based on results of unpaired one-tailed $t$-tests (comparing IgG-treated to integrin-blocked). 

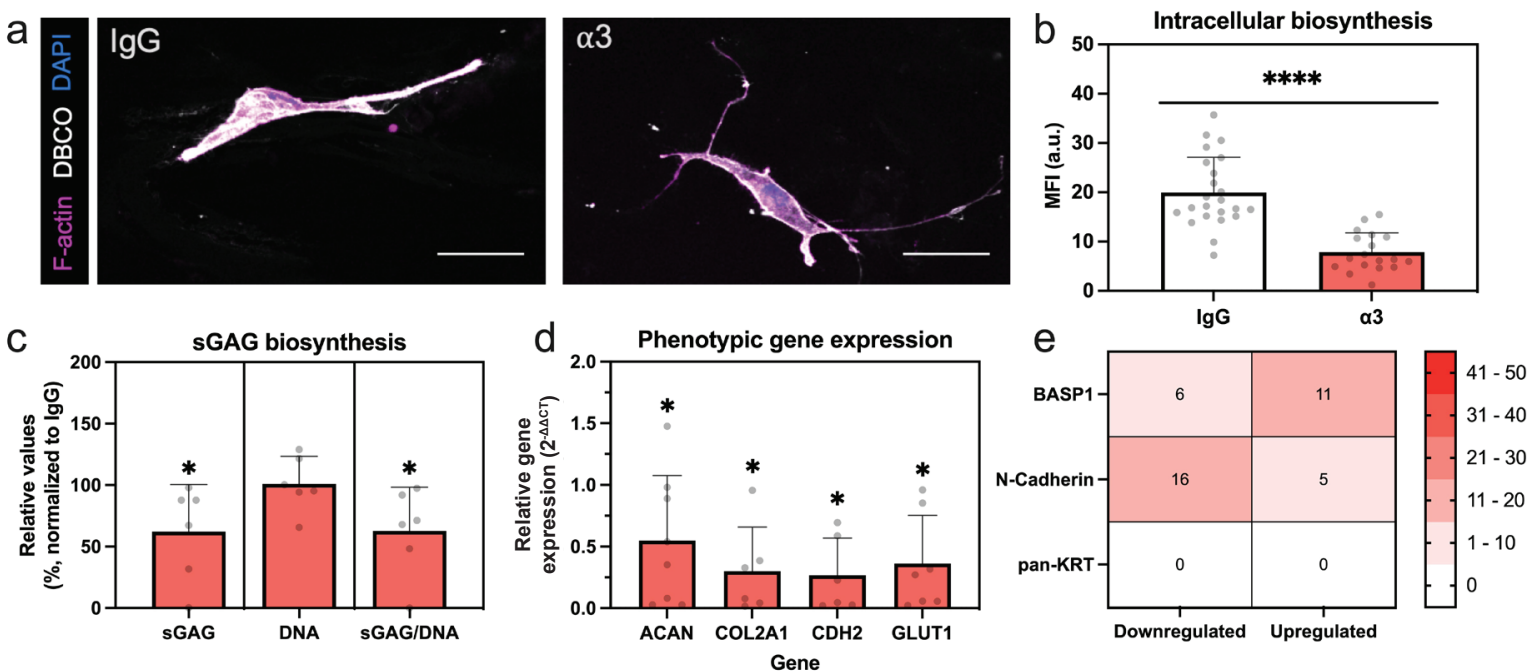

Fig. 5. Blocking integrin $\alpha 3$ reduces biosynthesis and expression of phenotypic markers. (a) Representative images using FUNCAT staining (nascent proteins labeled with DBCO $=$ white, F-actin = magenta, DAPI $=$ blue, scale bar $=50 \mu \mathrm{m})$. (b) Fluorescence of nascent protein staining within the cell body compared to the IgG-treated group (each dot $=1$ cell as obtained from $n=3$ biological replicates). (c) sGAG (left), DNA content (middle), and sGAG normalized by DNA content (right) in integrin $\alpha 3$-blocked cells compared to IgG, relative value $=100^{*}$ (integrin-blocked/IgG-treated), each dot $=1$ sample from $n=3$ biological replicates . (d) Relative gene expression of phenotypic markers in the $\alpha 3$-treated group compared to the housekeeping $18 S$ and $\operatorname{GAPDH}\left(1^{\text {st }} \Delta\right)$ and cells incubated with IgG control antibody $\left(2^{\text {nd }} \Delta\right)$, each dot $=1$ biological replicate. (e) Heatmap showing percentage of cells with downregulated (50\% lower than IgG-treated cells) or upregulated (50\% higher than IgG-treated cells) protein expression. For all data presented: error bars $=$ standard deviation; ${ }^{* * * *} p<0.0001, * p<0.05$ based on results of unpaired one-tailed $t$-tests (comparing IgG-treated to integrin-blocked).

a



d

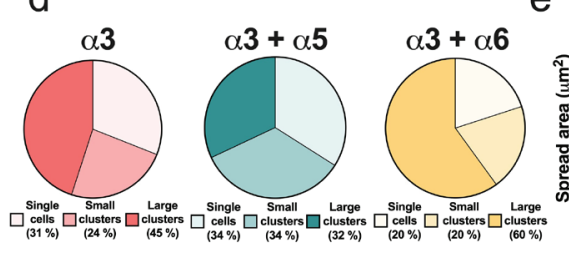

b

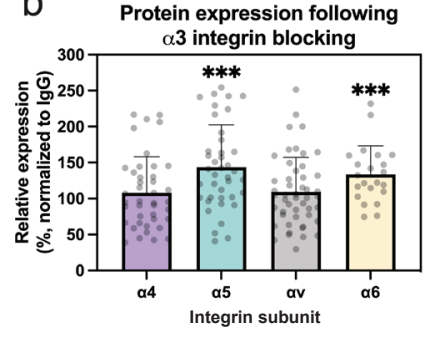

e
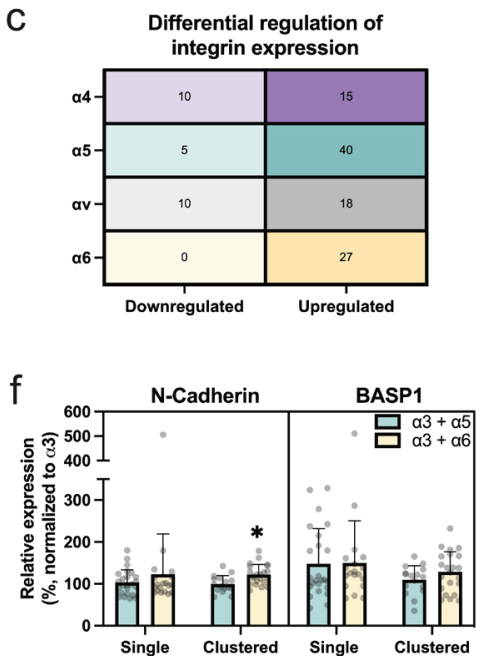

Fig. 6. Blocking integrin $\alpha 3$ alters integrin expression. (a) Relative gene expression of integrin subunits in the $\alpha 3$-treated group compared to the housekeeping genes $18 S$ and GAPDH $\left(1^{\text {st }} \Delta\right)$ and cells incubated with $\operatorname{IgG}$ control antibody $\left(2^{\text {nd }} \Delta\right)$, each dot $=1$ biological replicate. $($ b) Relative protein expression of integrin subunits in the $\alpha 3$-treated group compared to cells treated with IgG antibodies, relative expression $=100 \times$ (integrinblocked/IgG-treated), each dot $=1$ cell from $n=3$ biological replicates. (c) Proportion (\%) of adherent cells subjected to integrin $\alpha 3$ blocking with upregulated (50\% higher than IgG-treated) or downregulated (50\% lower than IgG-treated) integrin subunits. (d) \% of cells attaching to PEGLM as single cells, small clusters (2-3 cells), or large clusters (4+ cells) following inhibition of integrin $\alpha 3$ only or both integrins $\alpha 3+\alpha 5$ or $\alpha 3+\alpha 6$ (e) Spread area and circularity of single cells treated with integrin $\alpha 3$ only or both integrins $\alpha 3+\alpha 5$ or $\alpha 3+\alpha 6$, each dot $=1$ cell from $n=3$ biological replicates. (f) Relative protein expression of cells with both integrins $\alpha 3+\alpha 5$ or $\alpha 3+\alpha 6$ inhibited compared to cells with only $\alpha 3$ inhibited, relative expression $=100 \times($ dual integrin-blocked $/ \alpha 3$ integrin-blocked $)$, each dot $=1$ cell from $n=3$ biological replicates. For all data presented: error bars $=$ standard deviation; ${ }^{* * *} p<0.001,{ }^{*} p<0.05, \# p<0.09$ based on results of (a) paired two-tailed $t$-test of $\Delta \mathrm{Ct}$ values of integrin-blocked to IgG-treated (b) unpaired two-tailed $t$-test of MFI of integrin-blocked compared to IgG-treated (e,f) Ordinary one-way ANOVA with Dunnett's post hoc test comparing dual integrin-blocked to single integrin-blocked ( $\alpha 3$ only). 
These observed differences in cytoskeletal structure, while statistically significant, were modest. However, recent studies on NP cells have demonstrated that altered actin alignment, even when relatively slight, can result in significant changes to NP cell phenotype (Barcellona et al., 2020; Fearing et al., 2020). For example, inhibition of YAP signaling, and a subsequent promotion of cell rounding, reduced actin coherency $\sim 60 \%$ and resulted in the differential regulation of over 9,000 genes in degenerative human NP cells (Fearing et al., 2020).

\section{Inhibition of NP cells with antibodies to block integrin $\alpha 3$ alters biosynthesis}

Using FUNCAT techniques, newly synthesized proteins were fluorescently labeled in cells treated with the IgG control or antibodies to target integrin $\alpha 3$ (Fig. 5a). Intracellular fluorescence, a surrogate for nascent protein production, was reduced when integrin $\alpha 3$ was blocked ( $p<0.0001$, Fig. 5b). Additionally, the area containing newly produced extracellular proteins was lower on average in the integrin $\alpha 3$-blocked group (data not shown). DMMB and Picogreen assays were performed to specifically examine production of sGAG. While DNA content was not significantly different between the IgG and $\alpha 3$ integrin groups ( $p=0.46$, Fig. 5c), total sGAG production and normalized sGAG production were reduced in the integrin-blocked samples $(p=0.047$ and $p=0.025$, respectively, Fig. 5c).

Inhibition of integrin $\alpha 3$ alters NP cell phenotype Blocking integrin $\alpha 3$ elicited sustained effects on cell phenotype at the gene level. The gene expression of all phenotypic markers was decreased compared to the isotype control (Fig. 5d; ACAN: $p=0.023$; COL2A1: $p=0.025$; CDH2: $p=0.036$; and GLUT1: $p=0.019)$. Protein expression for several NP markers was also altered by blocking integrin $\alpha 3$, though heterogeneity was seen across the cell populations and thus the percentage of cells with upregulated (at least $50 \%$ greater) and downregulated (at least $50 \%$ lower) expression was quantified. BASP1 expression was downregulated in $6 \%$ of cells and cell clusters and upregulated in $11 \%$ of cells and cell clusters, while $\mathrm{N}$-cadherin was downregulated in $16 \%$ of cells/clusters and upregulated in $5 \%$ (Fig. 5e). In contrast, expression of cytokeratins (pan-KRT) was not differentially expressed following integrin blocking (Fig. 5e).

In addition to phenotypic markers, integrin expression was quantified following inhibition of integrin $\alpha 3$. Gene expression of integrin subunits was altered (ITGA6 $p=0.054$; ITGA10 $p=0.036$; ITGA11 $p=0.039$; ITGB1 $p=0.037$; ITGB4 $p=0.024$; Fig. 6a) in $\alpha 3$-treated compared to IgG-treated cells. Compared to cells in the control group, blocking integrin $\alpha 3$ promoted the increased protein expression of integrin $\alpha 5(p=0.0001)$ and $\alpha 6(p=0.0009)$, but not $\alpha 4(p=0.48)$ or $\alpha \mathrm{v}(p=0.30$, Fig. $6 \mathbf{b})$. Additional quantification revealed that $15-40 \%$ of cells/cell clusters upregulated
(50\% increase in protein expression) integrins $\alpha 4, \alpha 5$, $\alpha \mathrm{v}$, or $\alpha 6$ at the protein level following incubation with integrin $\alpha 3$-blocking antibodies (Fig. 6c), while downregulation (50\% lower protein expression) was seen in $0-10 \%$ of the cells. As integrins $\alpha 5$ and $\alpha 6$ demonstrated increased expression following blocking of integrin $\alpha 3$, these two proteins were explored further to determine if they function to compensate for the loss of integrin $\alpha 3$.

When integrins $\alpha 5$ or $\alpha 6$ were blocked following $24 \mathrm{~h}$ of integrin $\alpha 3$ inhibition, altered distributions in cell morphology (single cells, small clusters, large clusters) were observed compared to cells where $\alpha 3$ alone was blocked $(p<0.00001$, and $p=0.045$, respectively, Fig. 6d). Increased small or large cell clusters were observed to form in cells with $\alpha 3$ and $\alpha 5$ or $\alpha 3$ and $\alpha 6$ blocked, respectively, compared to cells treated with the $\alpha 3$ antibody alone (Fig. 6d). In contrast, neither cell spread area nor circularity of single cells (Fig. 6e) were altered for either of the double blocked conditions compared to cells with $\alpha 3$ blocked alone (spread area: $\alpha 3+\alpha 5, p=0.82$; $\alpha 3+\alpha 6, p=0.12$; circularity: $\alpha 3+\alpha 5, p=0.88 ; \alpha 3+\alpha 6$, $p=0.59)$. To explore whether cell-cell interactions are able to compensate for the additional loss of integrin function, protein expression was quantified for single cells and cell clusters subjected to the integrin blocking. $\mathrm{N}$-cadherin expression was similar in single cells when inhibiting integrin $\alpha 3$ compared to cells with either inhibition of integrins $\alpha 3$ and $\alpha 5$ or $\alpha 3$ and $\alpha 6$ ( $p=0.96$ and $p=0.24$ respectively; Fig. $6 \mathrm{f}$ left). In multi-cell clusters, $\mathrm{N}$-cadherin expression was elevated when inhibiting integrins $\alpha 3$ and $\alpha 6$ $(p=0.045)$ but not when integrins $\alpha 3$ and $\alpha 5$ were inhibited ( $p=0.9621$; Fig. 6f left). Average expression of BASP1 was not different between conditions where integrin $\alpha 3$ alone was blocked compared to blocking $\alpha 3$ and $\alpha 5$ or $\alpha 3$ and $\alpha 6$ for either single cells or cells in multi-cell clusters (Fig. $6 \mathrm{f}$ right; $p>0.26$ for all comparisons).

\section{Discussion}

Data from the present study demonstrated that integrin $\alpha 3$ plays a critical role in transducing cues from full-length laminin to adult human degenerative NP cells. When this subunit was inhibited, cell signaling and attachment were altered and the expression of markers of the healthy NP cell phenotype, that have previously been shown to be induced by the presence of laminin, were reduced. These findings illustrate the mechanisms by which previously developed laminin-presenting substrates have promoted cells to assume behaviors consistent with the healthy NP cell phenotype and can also be used to inform strategies for designing materials for treating intervertebral disc degeneration.

Laminins are found in the ECM of the developing and juvenile NP and NP cells have been shown to express integrins which interact with these proteins 
(Bridgen et al., 2013; Chen et al., 2009; Gilchrist et al., 2011b; Hayes et al., 2001; Nettles et al., 2004; Sun et al., 2017). Data from the present study corroborate prior findings that adult degenerative NP cells express integrins, specifically $\alpha 3, \alpha 4, \alpha 5, \alpha \mathrm{v}, \alpha 6$, and $\beta 1$ subunits. While multiple integrin subunits are present at the membranes of the degenerative NP cells, results of the cell attachment assay indicate that blocking integrins $\alpha 3$ or $\alpha 5$ alone is sufficient to reduce initial cell attachment to PEGLM. Additionally, impairment of integrin $\beta 1$ and, therefore, the heterodimers which form with integrin $\beta 1$ (including $\alpha 3 \beta 1, \alpha 6 \beta 1$, $\alpha 1 \beta 1, \alpha 2 \beta 1, \alpha 5 \beta 1, \alpha 4 \beta 1$, and $\alpha 10 \beta 1)$ significantly reduced NP cell attachment (Humphries et al., 2006; Hynes and Naba, 2012). These findings expand on previous literature which has demonstrated a role for multiple integrin subunits in mediating attachment to full-length laminins adsorbed to surfaces, and further confirms that adhesive sites within the laminin remain accessible to cells when the protein is conjugated to the biomaterial (Bridgen et al., 2013; Francisco et al., 2013).

Integrins not only promote attachment to ECM proteins, but also serve critical functions as mechanotransducers due to their intracellular interactions with the cytoskeleton and with hundreds of signaling molecules that regulate diverse cellular functions (Giancotti and Ruoslahti, 1999; WinogradKatz et al., 2014; Yamada and Miyamoto, 1995). Studies in other cell types have demonstrated that modulating integrin function impacts cell signaling profiles (Chen et al., 2016; Ferletta et al., 2003; Velpula et al., 2012). Quantification of protein phosphorylation in the present study similarly confirmed that engagement of degenerative NP cells with PEGLM initiates ERK $1 / 2$ and GSK3 $\beta$ signal transduction pathways in an integrin-dependent mechanism. The data demonstrated that blocking integrin $\alpha 3$ reduced phosphorylation for both signaling molecules, whereas inhibiting the other integrin subunits tested either elicited less pronounced results or showed responses that differed between the two signaling pathways. Taking the outcomes of cell attachment and signaling together, it can be seen that integrin $\alpha 3$ is the primary mediator of adult degenerative NP cell interactions with PEGLM at early time points $(\leq 2 \mathrm{~h})$, events that are known to drive other cellular behaviors such as cell shape, biosynthesis, and phenotype.

At prolonged time points, cells incubated with integrin $\alpha 3$ blocking antibodies demonstrated alterations in the proportion of cells attaching to PEGLM as single cells or clusters and the single cells also showed increased cell spread areas and decreased circularity. Modulation of cell morphology has been previously shown to control phenotype and global transcriptome (Kilian et al., 2010; McWhorter et al., 2013). This effect has been confirmed in NP cells as well, with decreased intracellular tension and a concomitant rounding of cells on PEGLM being associated with increased expression of markers of the NP juvenile phenotype (Barcellona et al., 2020; Fearing et al., 2020; Francisco et al., 2014). In the present study, the altered cell shape observed in the $\alpha 3$-blocked cells may be due in part to the reduced ability of these cells to form elongated paxillin-rich focal adhesions. Paxillin is a member of the focal adhesion proteome, and is essential for the formation, disassembly, and maturation of FAs following integrin activation, allowing for the regulation of cytoskeletal organization, generation of contractile forces, and cell motility (Deakin and Turner, 2008; Larsen et al., 2006; Miranti and Brugge, 2002; Yamada and Miyamoto, 1995). While the precise role of FA number and shape as it pertains to regulating NP cell phenotype is not well known, studies in other cell types have demonstrated a relationship between focal adhesion size/shape and cellular fate (Besser and Safran, 2006; Kim and Wirtz, 2013).

Integrin $\alpha 3$-mediated interactions with PEGLM controlled focal adhesion structures and actin alignment, which in turn modulated cell shape and phenotype (Fig. 7). Specifically, the data reveal that integrin $\alpha 3$ function is required for NP cells to re-express ACAN, CDH2, GLUT1, and COL2A1 and production of sGAGs, as has been previously shown for NP cells on hydrogels made from PEGLM. However, inhibition of integrin $\alpha 3$ was unable to eliminate expression of all the phenotype markers tested at the protein level. This finding may be in part due to the half-life of these proteins (Jaitovich et al., 2008), but also suggests that other integrins (namely $\alpha 5$ and $\alpha 6$ ) may be trafficked to the membrane in order to compensate for the impairment of integrin $\alpha 3$ and may promote the continued protein expression of these markers (De Franceschi et al., 2015; Kurakawa et al., 2015; Mana et al., 2020). The observation that dual inhibition of integrin subunits did not further alter cell spread area, circularity or protein expression in single cells provides additional support that integrin $\alpha 3$ may be the primary mediator for cell-ECM interactions for adult NP cells on PEGLM. However, as when integrin $\alpha 3$ alone was blocked, simultaneous inhibition of multiple integrin subunits ( $\alpha 3$ and $\alpha 5$ or $\alpha 3$ and $\alpha 6$ ) further promoted the formation of cellcell interactions. Concurrent inhibition of integrins $\alpha 3$ and $\alpha 5$ caused increased formation of small cellclusters (where cell-ECM and cell-matrix interactions are relatively balanced); however, simultaneous inhibition of integrins $\alpha 3$ and $\alpha 6$ caused an increase in the presence of large cell clusters and thus, cellcell interactions. Clustered cells with both integrins $\alpha 3$ and $\alpha 6$ blocked did not demonstrate differential BASP1 expression, but did show increased expression of N-cadherin, a protein known to facilitate increased cell-cell interactions (Hwang et al., 2015; Marie, 2002). These findings are consistent with previous literature which has demonstrated that both cell-ECM and cellcell adhesions can modulate cell behaviors during development and pathology, but that shifting the balance can modulate cell fate (Cosgrove et al., 2016; Crowder et al., 2016; Gilchrist et al., 2011a; Hwang 


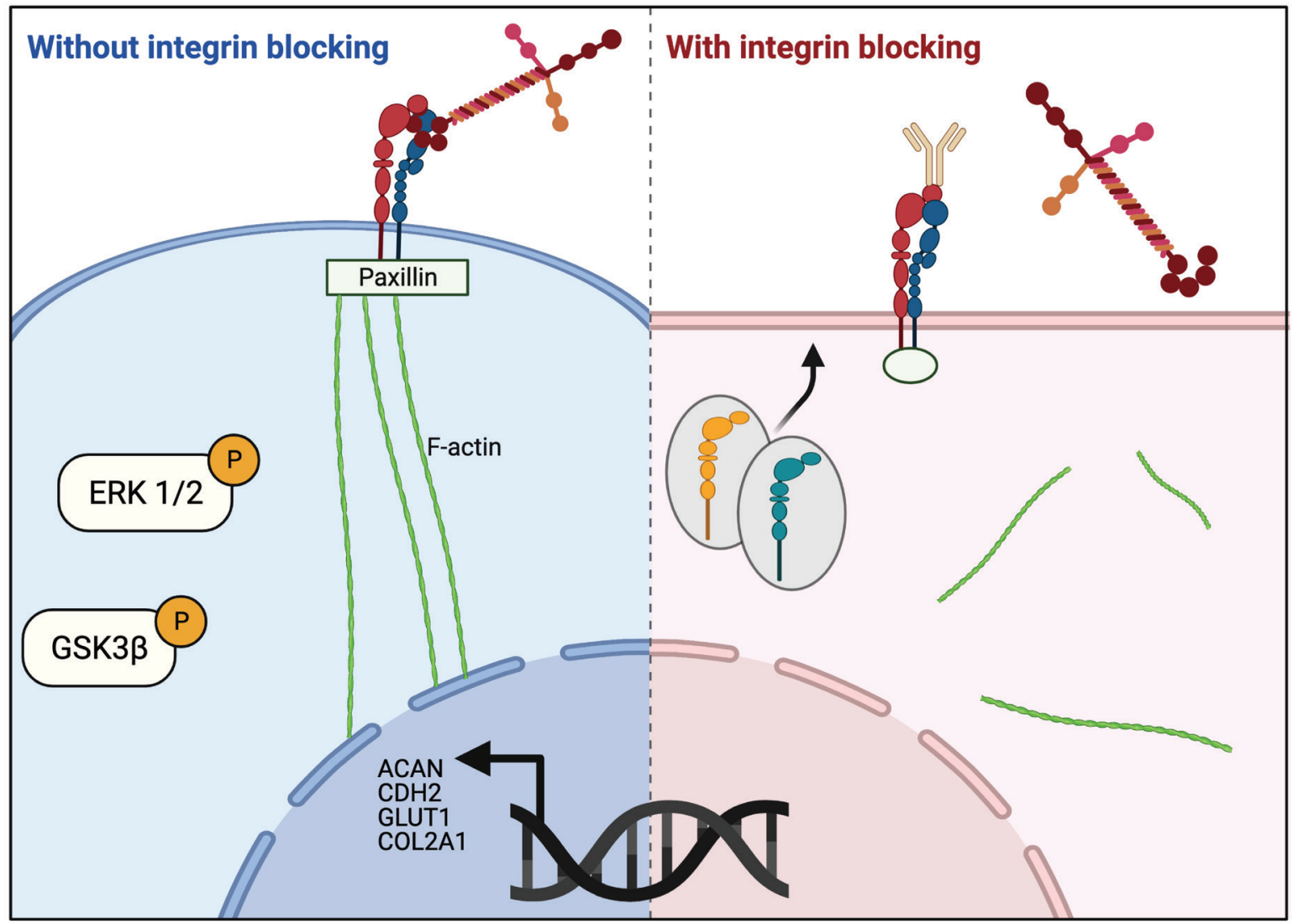

Fig. 7. Proposed model describing the effects of integrin $\alpha 3$ inhibition on NP cell behaviors. (Left) When integrin $\alpha 3$ is able to bind to the laminin proteins in PEGLM, larger, elongated paxillin-positive focal adhesions are able to form which stabilize the connection between the extracellular domain and the cytoskeleton which demonstrates more aligned F-actin fibers and promotes increased cell circularity. Integrin engagement also promotes phosphorylation of ERK $1 / 2$ and GSK3 $\beta$ and the transcription of phenotypic markers such as $A C A N, C D H 2$, GLUT1, and COL2A1. (Right) In contrast, when cells are treated with antibodies which block integrin $\alpha 3$, cells are unable to bind efficiently to the laminin in PEGLM. More circular paxillin-positive focal adhesions form and the cytoskeleton exhibits reduced F-actin alignment and a larger, less round cell shape. Reduced integrin engagement decreases ERK $1 / 2$ and GSK3 $\beta$ phosphorylation and phenotypic markers are transcribed less frequently. Additionally, integrin trafficking promotes increased expression of integrin $\alpha 5$ and $\alpha 6$. Image created using BioRender.com.

et al., 2014; Lauffenburger and Griffith, 2001; LindeMedina and Marcucio, 2018; McCain et al., 2012; Ryan et al., 2001). Additional studies, however, are required to further explore compensatory integrin-mediated mechanisms and to determine the relative roles of cell-cell and cell-matrix interactions in controlling NP cell behaviors. Data from the present study demonstrate that reduced cellular interactions with PEGLM (as caused by integrin inhibition) reduce this biomaterial's ability to regulate the phenotype of adult degenerative NP cells in a mechanism that is not fully counteracted by increased formation of cell-cell interactions (Gilchrist et al., 2011a; Kurakawa et al., 2015; Nelson and Chen, 2003).

Previous findings utilizing PEGLM or lamininmimetic peptides have demonstrated that NP cells can sense and respond to numerous features of the microenvironment including ligand presentation (Bridgen et al., 2017; Francisco et al., 2014; Gilchrist et al., 2011a), ligand density (Barcellona et al., 2020; Barcellona et al., 2021), and bulk substrate stiffness (Gilchrist et al., 2011a), and that all of these parameters have roles in biomaterial design and tissue engineering approaches. In the present study, PEGLM-coated polystyrene was utilized in order to evaluate the impact of laminin presentation on NP cell phenotype, without introducing the variable of substrate stiffness, which can itself promote altered cell phenotypes. Similarly, this study presents the results of 2D culture and thus future studies will be needed to confirm the roles of integrin subunits during 3D culture and in the in vivo, mechanically loaded, native environment. Another limitation of the present study is the use of only degenerative NP cells, and thus the inability to determine differences in mechanotransduction between degenerative and healthy NP cells. Previous studies have demonstrated that integrin expression may be altered by pathology and severity of degeneration; however, additional research is needed to determine if and how integrin expression varies and the contributions of integrins to the degenerative cascade in the disc (Kanda et al., 2020; Kurakawa et al., 2015; Le Maitre et al., 2009; Xia and Zhu, 2008). Furthermore, studies 
which overexpress or exogenously activate integrin $\alpha 3$ subunits may provide insight into additional therapeutic options for preventing or treating disc disease.

\section{Conclusion}

The data presented demonstrate that in the absence of integrin $\alpha 3$-mediated engagement with laminin, the cytoskeletal organization, gene expression of phenotypic markers, and biosynthesis of adult degenerative NP cells were significantly altered. Furthermore, blocking other integrin subunits in addition to $\alpha 3$ resulted in changes to cell morphology but overall phenotype was unaltered by continued integrin inhibition. This suggests that the $\alpha 3$ subunit plays a critical role in mediating phenotype for adult degenerative NP cells in culture on PEGLM. Together, these data demonstrate a mechanism of action for PEGLM, a clinically relevant material which can be used in the treatment of degenerative NP.

\section{Acknowledgments}

This research was supported by the National Institutes of Health, NIH (R01 AR070975, AR069588, AR077678), the National Science Foundation, NSF GRFP (Grant No. DGE-1745038) and the Spencer T. and Ann W. Olin Fellowship for Women in Graduate Study (Washington University in St. Louis). This publication is solely the responsibility of the authors and does not necessarily represent the official view of the NIH or the NSF.

We thank Dr. Bailey Fearing (Atrium Health Musculoskeletal Institute; Charlotte, NC) for providing assistance with the production of PEGLM and Dr. Chelsey Dunham (Johns Hopkins University, MD) for her guidance on the FUNCAT imaging technique.

\section{References}

Aplin AE, Stewart SA, Assoian RK, Juliano RL (2001) Integrin-mediated adhesion regulates ERK nuclear translocation and phosphorylation of Elk-1. J Cell Biol 153: 273-281.

Arboleda MJ, Lyons JF, Kabbinavar FF, Bray MR, Snow BE, Ayala R, Danino M, Karlan BY, Slamon DJ (2003) Overexpression of AKT2/Protein kinase $\mathrm{B} \beta$ leads to up-regulation of $\beta 1$ integrins, increased invasion, and metastasis of human breast and ovarian cancer cells. Cancer Res 63: 196-206.

Barcellona MN, Speer JE, Fearing B V, Jing L, Pathak A, Gupta MC, Buchowski JM, Kelly M, Setton LA (2020) Control of adhesive ligand density for modulation of nucleus pulposus cell phenotype. Biomaterials 250: 120057. DOI: 10.1016/j. biomaterials.2020.120057.
Barcellona MN, Speer JE, Jing L, Gupta MC, Buchowski JM, Kelly MP, Setton LA (2021) Engineered peptide-functionalized hydrogels modulate the RNA transcriptome of human nucleus pulposus cells in vitro. BioRxiv. DOI: 10.1101/2021.03.05.434094.

Barczyk M, Carracedo S, Gullberg D (2010) Integrins. Cell Tissue Res 339: 269-280.

Belkin AM, Stepp MA (2000) Integrins as receptors for laminins. Microsc Res Tech 51: 280-301.

Besser A, Safran SA (2006) Force-induced adsorption and anisotropic growth of focal adhesions. Biophys J 90: 3469-3484.

Blaustein M, Pérez-Munizaga D, Sánchez MA, Urrutia C, Grande A, Risso G, Srebrow A, Alfaro J, Colman-Lerner A (2013) Modulation of the Akt pathway reveals a novel link with PERK/eIF2 $\alpha$, which is relevant during hypoxia. PLoS One 8: e69668. DOI: 10.1371/journal.pone.0069668.

Bowles RD, Masuda K, Bonassar LA, Setton LA (2014) Tissue engineering for regeneration and replacement of the intervertebral disc. In Principles of Tissue Engineering, 4th Edition, Ed Lanza R., Langer R., Vacanti J., pp.1223-1251. Academic Press, London.

Bridgen DT, Gilchrist CL, Richardson WJ, Isaacs RE, Brown CR, Yang KL, Chen J, Setton LA (2013) Integrin-mediated interactions with extracellular matrix proteins for nucleus pulposus cells of the human intervertebral disc. J Orthop Res 31: 1661-1667.

Bridgen DT, Fearing B V, Jing L, Sanchez-Adams J, Cohan MC, Guilak F, Chen J, Setton LA (2017) Regulation of human nucleus pulposus cells by peptide-coupled substrates. Acta Biomater 55: 100108.

Chan WCW, Sze KL, Samartzis D, Leung VYL, Chan D (2011) Structure and biology of the intervertebral disk in health and disease. Orthop Clin North Am 42: 447-464.

Chen H, Qu J, Huang X, Kurundkar A, Zhu L, Yang N, Venado A, Ding Q, Liu G, Antony VB, Thannickal VJ, Zhou Y (2016) Mechanosensing by the $\alpha 6$-integrin confers an invasive fibroblast phenotype and mediates lung fibrosis. Nat Commun 7: 12564. DOI: $10.1038 /$ ncomms12564.

Chen J, Jing L, Gilchrist CL, Richardson WJ, Fitch RD, Setton LA (2009) Expression of laminin isoforms, receptors, and binding proteins unique to nucleus pulposus cells of immature intervertebral disc. Connect Tissue Res 50: 294-306.

Choi Y, Park MH, Lee K (2019) Tissue engineering strategies for intervertebral disc treatment using functional polymers. Polymers (Basel) 11: 872. DOI: 10.3390/polym11050872.

Clouet J, Fusellier M, Camus A, Le Visage C, Guicheux J (2019) Intervertebral disc regeneration: from cell therapy to the development of novel bioinspired endogenous repair strategies. Adv Drug Deliv Rev 146: 306-324.

Cloyd JM, Malhotra NR, Weng L, Chen W, Mauck RL, Elliott DM (2007) Material properties in unconfined compression of human nucleus pulposus, 
injectable hyaluronic acid-based hydrogels and tissue engineering scaffolds. Eur Spine J 16: 1892-1898.

Cosgrove BD, Mui KL, Driscoll TP, Caliari SR, Mehta KD, Assoian RK, Burdick JA, Mauck RL (2016) N-cadherin adhesive interactions modulate matrix mechanosensing and fate commitment of mesenchymal stem cells. Nat Mater 15: 1297-1306.

Crowder SW, Leonardo V, Whittaker T, Papathanasiou P, Stevens MM (2016) Material cues as potent regulators of epigenetics and stem cell function. Cell Stem Cell 18: 39-52.

Deakin NO, Turner CE (2008) Paxillin comes of age. J Cell Sci 121: 2435-2444.

De Franceschi N, Hamidi H, Alanko J, Sahgal P, Ivaska J (2015) Integrin traffic - the update. J Cell Sci 128: 839-852.

Ding N, Ping L, Feng L, Zheng X, Song Y, Zhu J (2014) Histone deacetylase 6 activity is critical for the metastasis of Burkitt's lymphoma cells. Cancer Cell Int 14: 1-7.

Dunham C, Havlioglu N, Chamberlain A, Lake S, Meyer G (2020) Adipose stem cells exhibit mechanical memory and reduce fibrotic contracture in a rat elbow injury model. FASEB J 34: 12976-12990.

Farndale RW, Sayers CA, Barrett AJ (1982) A Direct spectrophotometric microassay for sulfated glycosaminoglycans in cartilage cultures. Connect Tissue Res 9: 247-248.

Faull RJ, Ginsberg MH (1996) Inside-out signaling through integrins. J Am Soc Nephrol 7: 1091-1097.

Fearing B V, Hernandez PA, Setton LA, ChahineNO (2018) Mechanotransduction and cell biomechanics of the intervertebral disc. JOR Spine 1: e1026. DOI: 10.1002/jsp2.1026.

Fearing B V, Jing L, Barcellona MN, Witte SE, Buchowski JM, Zebala LP, Kelly MP, Luhmann S, Gupta MC, Pathak A, Setton LA (2019) Mechanosensitive transcriptional coactivators MRTF-A and YAP/TAZ regulate nucleus pulposus cell phenotype through cell shape. FASEB J 33: $14022-$ 14035.

Fearing B V, Speer JE, Jing L, Kalathil A, Kelly M, Buchowski J, Zebala L, Luhmann S, Gupta M, Setton L (2020) Verteporfin treatment controls morphology, phenotype, and global gene expression for cells of the human nucleus pulposus. JOR Spine 3: e1111. DOI: 10.1002/jsp2.1111.

Ferletta M, Kikkawa Y, Yu H, Talts JF, Durbeej M, Sonnenberg A, Timpl R, Campbell KP, Ekblom P, Genersch E (2003) Opposing roles of integrin $\alpha 6 \mathrm{~A} \beta 1$ and dystroglycan in laminin-mediated extracellular signal-regulated kinase activation. Mol Biol Cell 14: 2088-2103.

Francisco AT, Hwang PY, Jeong CG, Jing L, Chen J, Setton LA (2014) Photocrosslinkable lamininfunctionalized polyethylene glycol hydrogel for intervertebral disc regeneration. Acta Biomater 10: 1102-1111.

Francisco AT, Mancino RJ, Bowles RD, Brunger JM, Tainter DM, Chen Y-T, Richardson WJ, Guilak F, Setton LA (2013) Injectable laminin-functionalized hydrogel for nucleus pulposus regeneration. Biomaterials 34: 7381-7388.

Freemont AJ (2008) The cellular pathobiology of the degenerate intervertebral disc and discogenic back pain. Rheumatology 48: 5-10.

Giancotti FG, Ruoslahti E (1999) Integrin signaling. Science 285: 1028-1033.

Gilbert HTJ, Hoyland JA, Millward-Sadler SJ (2010) The response of human anulus fibrosus cells to cyclic tensile strain is frequency-dependent and altered with disc degeneration. Arthritis Rheum 62: 3385-3394.

Gilchrist, CL, Cao, L, Setton, LA.(2013) Intervertebral disc cell mechanics and mechanobiology. In: Orthopaedic biomechanics, Winkelstein, BA (ed.). Boca Raton: CRC Press, pp.75-100.

Gilchrist CL, Chen J, Richardson WJ, Loeser RF, Setton LA (2007) Functional integrin subunits regulating cell-matrix interactions in the intervertebral disc. J Orthop Res 25: 829-840.

Gilchrist CL, Darling EM, Chen J, Setton LA (2011a) Extracellular matrix ligand and stiffness modulate immature nucleus pulposus cell-cell interactions. PLoS One 6: e27170. DOI: 10.1371/ journal.pone.0027170.

Gilchrist C, Francisco A, Plopper G, Chen J, Setton L (2011b) Nucleus pulposus cell-matrix interactions with laminins. Eur Cells Mater 21: 523-532.

Grzesiak JJ, Smith KC, Burton DW, Deftos LJ, Bouvet M (2005) GSK3 and PKB/Akt are associated with integrin-mediated regulation of PTHrP, IL-6 and IL-8 expression in FG pancreatic cancer cells. Int J Cancer 114: 522-530.

Hayes A, Benjamin M, Ralphs JR(2001) Extracellular matrix in development of the intervertebral disc. Matrix Biol 20: 107-121.

Hiyama A, Sakai D, Risbud M V., Tanaka M, Arai F, Abe K, Mochida J (2010) Enhancement of intervertebral disc cell senescence by WNT/ $\beta$ catenin signaling-induced matrix metalloproteinase expression. Arthritis Rheum 62: 3036-3047.

Hood JD, Cheresh DA (2002) Role of integrins in cell invasion and migration. Nat Rev Cancer 2: 91-100.

Horzum U, Ozdil B, Pesen-Okvur D (2014) Stepby-step quantitative analysis of focal adhesions. MethodsX 1: 56-59.

Hoy D, March L, Brooks P, Blyth F, Woolf A, Bain C, Williams G, Smith E, Vos T, Barendregt J, Murray C, Burstein R, Buchbinder R (2014) The global burden of low back pain: estimates from the Global Burden of Disease 2010 study. Ann Rheum Dis 73: 968-974.

Humphreys MD, Ward L, Richardson SM, Hoyland JA (2018) An optimized culture system for notochordal cell expansion with retention of phenotype. JOR Spine 1: e1028. DOI: 10.1002/ jsp2.1028.

Humphries JD, Byron A, Humphries MJ (2006) Integrin ligands at a glance. J Cell Sci 119: 3901-3903.

Hwang PY, Jing L, Michael KW, Richardson WJ, Chen J, Setton LA (2015) N-Cadherin-mediated signaling regulates cell phenotype for nucleus 
pulposus cells of the intervertebral disc. Cell Mol Bioeng 8: 51-62.

Hwang PY, Setton LA, Chen J, Jing L, Hoffman BD, Setton LA (2014) The role of extracellular matrix elasticity and composition in regulating the nucleus pulposus cell phenotype in the intervertebral disc: a narrative review. J Biomech Eng 136: 021010.

Hynes RO (1992) Integrins: versatility, modulation, and signaling in cell adhesion. Cell 69: 11-25.

Hynes RO, Naba A (2012) Overview of the matrisome - an inventory of extracellular matrix constituents and functions. Cold Spring Harb Perspect Biol 4: a004903. DOI: 10.1101/cshperspect.a004903.

Iatridis JC, Setton LA, Weidenbaum M, Mow VC (1997) Alterations in the mechanical behavior of the human lumbar nucleus pulposus with degeneration and aging. J Orthop Res 15: 318-322.

Iatridis JC, Weidenbaum M, Setton LA, Mow VC (1996) Is the nucleus pulposus a solid or a fluid? Mechanical behaviors of the nucleus pulposus of the human intervertebral disc. Spine (Phila Pa 1976) 21: 1174-1184.

Jaitovich A, Mehta S, Na N, Ciechanover A, Goldman RD, Ridge KM (2008) Ubiquitinproteasome-mediated degradation of keratin intermediate filaments in mechanically stimulated A549 cells. J Biol Chem 283: 25348-25355.

Kanda Y, Yurube T, Morita Y, Takeoka Y, Kurakawa T, Tsujimoto R, Miyazaki K, Kakiuchi Y, Miyazaki S, Zhang Z, Takada T, Hoshino Y, Masuda K, Kuroda R, Kakutani K (2020) Delayed notochordal cell disappearance through integrin $\alpha 5 \beta 1$ mechanotransduction during ex-vivo dynamic loading-induced intervertebral disc degeneration. J Orthop Res: 1-12.

Kandel R, Roberts S, Urban JPG (2008) Tissue engineering and the intervertebral disc: the challenges. Eur Spine J 17: S480-S491.

Katz JN (2006) Lumbar disc disorders and lowback pain: socioeconomic factors and consequences. J Bone Jt Surg 88-A: 21-24.

Kilian KA, Bugarija B, Lahn BT, Mrksich M (2010) Geometric cues for directing the differentiation of mesenchymal stem cells. Proc Natl Acad Sci 107: 4872-4877.

Kim DH, Wirtz D (2013) Focal adhesion size uniquely predicts cell migration. FASEB J 27: 13511361.

Kim J-M, Park WH, Min B-M (2005) The PPFLMLLKGSTR motif in globular domain 3 of the human laminin- $5 \alpha 3$ chain is crucial for integrin $\alpha 3 \beta 1$ binding and cell adhesion. Exp Cell Res 304: 317-327.

Kurakawa T, Kakutani K, Morita Y, Kato Y, Yurube T, Hirata H, Miyazaki S, Terashima Y, Maeno K, Takada T, Doita M, Kurosaka M, Inoue N, Masuda K, Nishida K (2015) Functional impact of integrin $\alpha 5 \beta 1$ on the homeostasis of intervertebral discs: a study of mechanotransduction pathways using a novel dynamic loading organ culture system. Spine J 15: 417-426.
Lai C-F, Chaudhary L, Fausto A, Halstead LR, Ory DS, Avioli L V., Cheng S-L (2001) Erk is essential for growth, differentiation, integrin expression, and cell function in human osteoblastic cells. J Biol Chem 276: 14443-14450.

Larsen M, Artym V V., Green JA, Yamada KM (2006) The matrix reorganized: extracellular matrix remodeling and integrin signaling. Curr Opin Cell Biol 18: 463-471.

Lauffenburger DA, Griffith LG (2001) Who's got pull around here? Cell organization in development and tissue engineering. Proc Natl Acad Sci U S A 98: 4282-4284.

Legate KR, Wickstrom SA, Fassler R (2009) Genetic and cell biological analysis of integrin outside-in signaling. Genes Dev 23: 397-418.

Le Maitre CL, Frain J, Millward-Sadler J, Fotheringham AP, Freemont AJ, Hoyland JA (2009) Altered integrin mechanotransduction in human nucleus pulposus cells derived from degenerated discs. Arthritis Rheum 60: 460-469.

Lim C-H, Jee W-H, Son BC, Kim D-H, Ha K-Y, Park C-K (2005) Discogenic lumbar pain: association with MR imaging and CT discography. Eur J Radiol 54: 431-437.

Linde-Medina M, Marcucio R (2018) Living tissues are more than cell clusters: The extracellular matrix as a driving force in morphogenesis. Prog Biophys Mol Biol 137: 46-51.

Mana G, Valdembri D, Serini G (2020) Conformationally active integrin endocytosis and traffic: why, where, when and how? Biochem Soc Trans 48: 83-93.

Marie PJ (2002) Role of N-cadherin in bone formation. J Cell Physiol 190: 297-305.

McCain ML, Lee H, Aratyn-Schaus Y, Kleber AG, Parker KK (2012) Cooperative coupling of cell-matrix and cell-cell adhesions in cardiac muscle. Proc Natl Acad Sci U S A 109: 9881-9886.

McLeod CM, Mauck RL (2016) High fidelity visualization of cell-to-cell variation and temporal dynamics in nascent extracellular matrix formation. Sci Rep 6: 38852. DOI: 10.1038/srep38852.

McWhorter FY, Wang T, Nguyen P, Chung T, Liu WF (2013) Modulation of macrophage phenotype by cell shape. Proc Natl Acad Sci U S A 110: 17253-17258.

Miranti CK, Brugge JS (2002) Sensing the environment: a historical perspective on integrin signal transduction. Nat Cell Biol 4: E83-E90.

Mizushima H, Takamura H, Miyagi Y, Kikkawa Y, Yamanaka N, Yasumitsu H, Misugi K, Miyazaki K (1997) Identification of integrin-dependent andindependent cell adhesion domains in $\mathrm{COOH}-$ terminal globular region of laminin-5 a3 chain. Cell Growth Differ 8: 979-987.

Nachemson AL (1981)Disc pressuremeasurements. Spine (Phila Pa 1976) 6: 93-97.

Neidlinger-Wilke C, Galbusera F, Pratsinis H, Mavrogonatou E, Mietsch A, Kletsas D, Wilke H-J (2014) Mechanical loading of the intervertebral disc: 
from the macroscopic to the cellular level. Eur Spine J 23: S333-S343.

Nelson CM, Chen CS (2003) VE-cadherin simultaneously stimulates and inhibits cell proliferation by altering cytoskeletal structure and tension. J Cell Sci 116: 3571-3581.

Nettles DL, Richardson WJ, Setton LA (2004) Integrin expression in cells of the intervertebral disc. J Anat 204: 515-520.

Nomizu M, Kim WH, Yamamura K, Utani A, Song S, Otaka A, Roller PP, Kleinman HK, Yamada Y (1995) Identification of cell binding sites in the laminin $\alpha 1$ chain carboxyl-terminal globular domain by systematic screening of synthetic peptides. J Biol Chem 270: 20583-20590.

Nomizu M, Kuratomi Y, Ponce ML, Song S, Miyoshi K, Otaka A, Powell SK, Hoffman MP, Kleinman HK, Yamada Y (2000) Cell adhesive sequences in mouse laminin $\beta 1$ chain. Arch Biochem Biophys 378: 311-320.

Nomizu M, Kuratomi Y, Song S-Y, Ponce ML, Hoffman MP, Powell SK, Miyoshi K, Otaka A, Kleinman HK, Yamada Y (1997) Identification of cell binding sequences in mouse laminin $\gamma 1$ chain by systematic peptide screening. J Biol Chem 272: 32198-32205.

Ouyang A, Cerchiari AE, Tang X, Liebenberg E, Alliston T, Gartner ZJ, Lotz JC (2017a) Effects of cell type and configuration on anabolic and catabolic activity in 3D co-culture of mesenchymal stem cells and nucleus pulposus cells. J Orthop Res 35: 61-73.

Ouyang Z, Wang W-J, Yan Y, Wang B, Lv G (2017b) The PI3K/Akt pathway: a critical player in intervertebral disc degeneration. Oncotarget 8: 5787057881.

Pfirrmann CWA, Metzdorf A, Zanetti M, Hodler J, Boos N (2001) Magnetic resonance classification of lumbar intervertebral disc degeneration. Spine (Phila Pa 1976) 26: 1873-1878.

Püspöki Z, Storath M, Sage D, Unser M (2016) Transforms and operators for directional bioimage analysis: a survey. Adv Anat Embryol Cell Biol 219: 69-93.

Rasmussen DGK, Karsdal MA (2016) Laminins. In: Biochemistry of Collagens, Laminins and Elastin 1st Ed. Structure, Function and Biomarkers Ed Karsdal M.A., Leeming D.J., Henriksen K., Bay-Jensen A-C., London, Elsevier Inc. pp.163-196.

Ravindra VM, Senglaub SS, Rattani A, Dewan MC, Härtl R, Bisson E, Park KB, Shrime MG (2018) Degenerative lumbar spine disease: estimating global incidence and worldwide volume. Glob Spine J 8: 784-794.

Risbud M V., Schoepflin ZR, Mwale F, Kandel RA, Grad S, Iatridis JC, Sakai D, Hoyland JA (2015) Defining the phenotype of young healthy nucleus pulposus cells: recommendations of the Spine Research Interest Group at the 2014 annual ORS meeting. J Orthop Res 33: 283-293.
Roughley PJ (2004) Biology of intervertebral disc aging and degeneration. Spine (Phila Pa 1976) 29: 2691-2699.

Ryan PL, Foty RA, Kohn J, Steinberg MS (2001) Tissue spreading on implantable substrates is a competitive outcome of cell-cell vs. cell-substratum adhesivity. Proc Natl Acad Sci U S A 98: 4323-4327.

Sage D, Neumann FR, Hediger F, Gasser SM, Unser M (2005) Automatic tracking of individual fluorescence particles: application to the study of chromosome dynamics. IEEE Trans Image Process 14: 1372-1383.

Saleem S, Li J, Yee S-P, Fellows GF, Goodyer CG, Wang R (2009) B1 integrin/FAK/ERK signalling pathway is essential for human fetal islet cell differentiation and survival. J Pathol 219: 182-192.

Schindelin J, Arganda-Carreras I, Frise E, Kaynig V, Longair M, Pietzsch T, Preibisch S, Rueden C, Saalfeld S, Schmid B, Tinevez J, White DJ, Hartenstein V, Eliceiri K, Tomancak P, Cardona A (2012) Fiji: an open-source platform for biological-image analysis. Nat Methods 9: 676-682.

Setton LA, Chen J (2006) Mechanobiology of the intervertebral disc and relevance to disc degeneration. J Bone Jt Surg 88: 52-57.

Sun Y, Wang T, Toh W, Pei M (2017) The role of laminins in cartilaginous tissues: from development to regeneration. Eur Cells Mater 34: 40-54.

Takada Y, Ye X, Simon S (2007) The integrins. Genome Biol 8: 215.1-215.9.

Tang X, Richardson WJ, Fitch RD, Brown CR, Isaacs RE, Chen J (2014) A new non-enzymatic method for isolating human intervertebral disc cells preserves the phenotype of nucleus pulposus cells. Cytotechnology 66: 979-986.

tom Dieck S, Kochen L, Hanus C, Bartnik I, Nassim-Assir B, Merk K, Mosler T, Garg S, Bunse S, Tirrell DA, Schuman EM (2015) Direct visualization of newly synthesized target proteins in situ. Nat Methods 12: 411-414.

Tsai T-T, Cheng C-M, Chen C-F, Lai P-L (2014) Mechanotransduction in intervertebral discs. J Cell Mol Med 18: 2351-2360.

Tsai T-T, Guttapalli A, Agrawal A, Albert TJ, Shapiro IM, Risbud MV (2007) MEK/ERK signaling controls osmoregulation of nucleus pulposus cells of the intervertebral disc by transactivation of TonEBP/ OREBP. J Bone Miner Res 22: 965-974.

Urban JPG, Roberts S, Ralphs JR (2000) The nucleus of the intervertebral disc from development to degeneration. Am Zool 40: 53-61.

Urban JPG, Roberts S (1995) Development and degeneration of the intervertebral discs. Mol Med Today 1: 329-335.

Urban JPG, Roberts S (2003) Degeneration of the intervertebral disc. Arthritis Res Ther 5: 120-130.

Velpula KK, Rehman AA, Chelluboina B, Dasari VR, Gondi CS, Rao JS, Veeravalli KK (2012) Glioma stem cell invasion through regulation of the 
interconnected ERK, integrin $\alpha 6$ and N-cadherin signaling pathway. Cell Signal 24: 2076-2084.

Walter BA, Mageswaran P, Mo X, Boulter DJ, Mashaly H, Nguyen X V, Prevedello LM, Thoman W, Raterman BD, Kalra P, Mendel E, Marras WS, Kolipaka A (2017) MR elastography-derived stiffness: a biomarker for intervertebral disc degeneration. Radiology 285: 167-175.

Weber KT, Jacobsen TD, Maidhof R, Virojanapa J, Overby C, Bloom O, Quraishi S, Levine M, Chahine NO (2015) Developments in intervertebral disc disease research: pathophysiology, mechanobiology, and therapeutics. Curr Rev Musculoskelet Med 8: 18-31.

Winograd-Katz SE, Fässler R, Geiger B, Legate KR (2014) The integrin adhesome: from genes and proteins to human disease. Nat Rev Mol Cell Biol 15: 273-288.
Xia M, Zhu Y (2008) Expression of integrin subunits in the herniated intervertebral disc. Connect Tissue Res 49: 464-469.

Yamada K, Miyamoto S (1995) Integrin transmembrane signaling and cytoskeletal control. Curr Opin Cell Biol 7: 681-689.

Zhu Y, Cankova Z, Iwanaszko M, Lichtor S, Mrksich M, Ameer GA (2018) Potent laminin-inspired antioxidant regenerative dressing accelerates wound healing in diabetes. Proc Natl Acad Sci U S A 115: 6816-6821.

Editor's note: There were no questions from reviewers for this paper, therefore there is no Discussion with Reviewers section. The Scientific Editor responsible for this paper was Mauro Alini. 